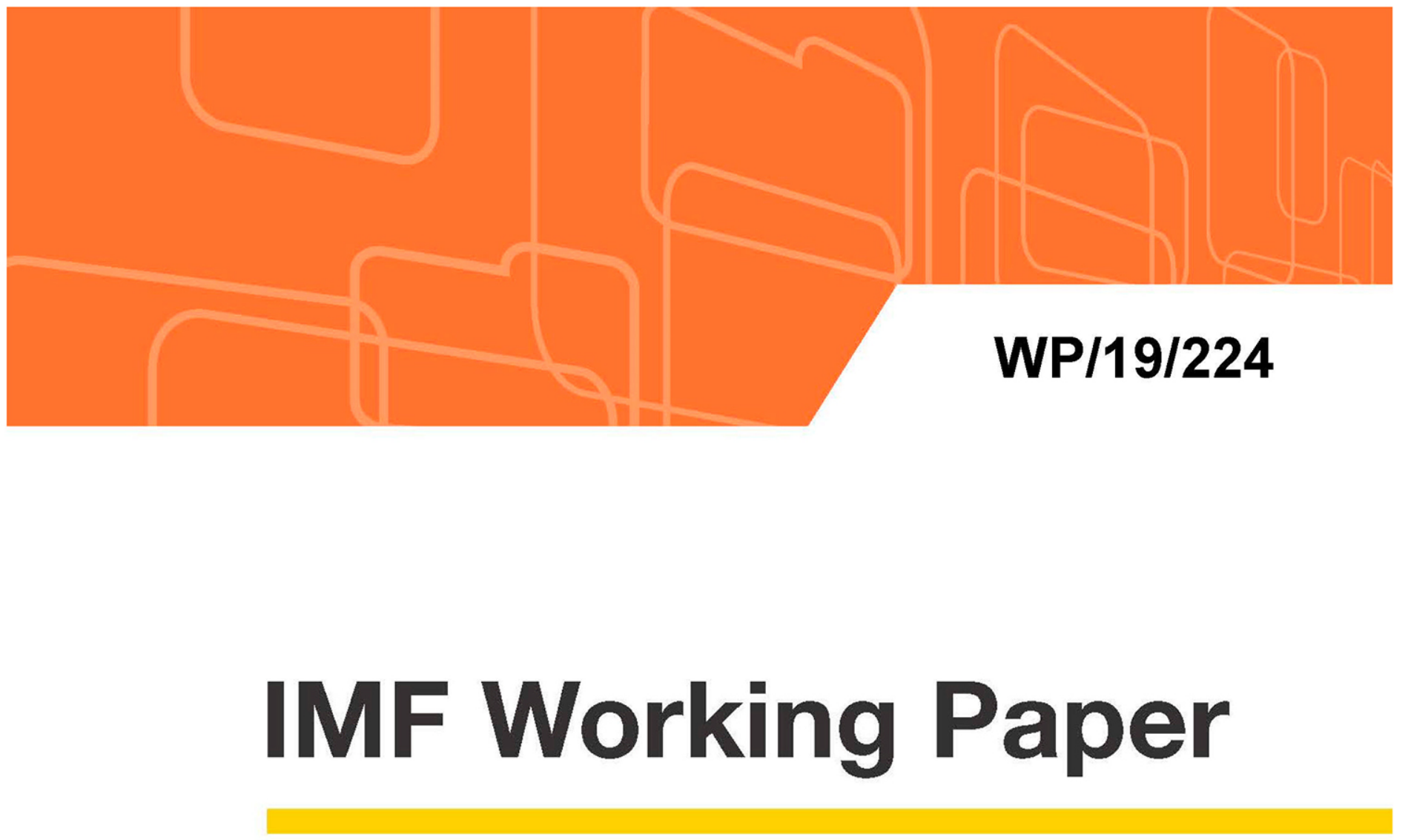

\title{
Banks' Holdings of Government Securities and Credit to the Private Sector in Emerging Market and Developing Economies
}

by Romain Bouis

IMF Working Papers describe research in progress by the author(s) and are published to elicit comments and to encourage debate. The views expressed in IMF Working Papers are those of the author(s) and do not necessarily represent the views of the IMF, its Executive Board, or IMF management. 




\title{
Banks' Holdings of Government Securities and Credit to the Private Sector in Emerging Market and Developing Economies
}

\author{
by Romain Bouis
}

IMF Working Papers describe research in progress by the author(s) and are published to elicit comments and to encourage debate. The views expressed in IMF Working Papers are those of the author(s) and do not necessarily represent the views of the IMF, its Executive Board, or IMF management.

$$
\text { I N T E R N A T I O N A L M O N E T A R Y F U N D }
$$




\title{
IMF Working Paper
}

Monetary and Capital Markets Department

\section{Banks' Holdings of Government Securities and Credit to the Private Sector in Emerging Market and Developing Economies}

\author{
Prepared by Romain Bouis*
}

Authorized for distribution by Ulric Eriksson von Allmen

October 2019

\section{IMF Working Papers describe research in progress by the author(s) and are published to elicit comments and to encourage debate. The views expressed in IMF Working Papers are those of the author(s) and do not necessarily represent the views of the IMF, its Executive Board, or IMF management.}

\begin{abstract}
This paper studies the relationship between banks' holdings of domestic sovereign securities and credit growth to the private sector in emerging market and developing economies. Higher banks' holdings of government debt are associated with a lower credit growth to the private sector and with a higher return on assets of the banking sector. Analysis suggests that the negative relationship between banks' claims on the government and private sector credit growth mainly reflects a portfolio rebalancing of banks towards safer, more liquid public assets in stress times and provides only limited evidence of a crowding-out effect due to financial repression.

JEL Classification Numbers: G21; G28; G30.

Keywords: Sovereign debt; credit growth; bank profitability; nonperforming loans; portfolio rebalancing; financial repression; crowding-out.

Author's E-Mail Address: rbouis@imf.org

* This paper benefited from helpful comments and suggestions by Reda Cherif, Ulric Eriksson von Allmen, Papa N'Diaye, Mahvash Qureshi, David Robinson, Torsten Wezel, from participants to an internal IMF seminar, and other IMF colleagues. Thank you to Cleary Haines for excellent statistical support. Any errors and omissions are mine.
\end{abstract}


Abstract

I. Introduction

II. Data and Descriptive Statistics

III. Empirical Analysis

A. Credit Growth to the Private Sector

B. Banks' Claims on the Government

IV. Conclusion $\underline{22}$

References $\underline{23}$

Figures

1. Banks' Holdings of Sovereign Debt in AEs and EMDEs $\underline{6}$

2. Changes in Banks' Holdings of Sovereign Debt in EMDEs 7

3. Changes in Banks' Holdings of Sovereign Debt and in Public Debt

4. Banks' Holdings of Public Debt and Credit Growth to the Private Sector $\underline{8}$

Tables

1. Banks' Claims on the Government and Credit Growth to the Private Sector 12

2. Determinants of Banks' Holdings of Government Debt 16

3. Banks' Claims on the Government and After-Tax ROA 19

4. Banks' Claims on the Government, ROA Before Taxes, and NIM

$\underline{21}$

Appendix Tables

1. Variable Definition and Sources $\underline{25}$

2. Countries of the Estimation Sample

$\underline{26}$




\section{INTRODUCTION}

Holdings of public debt by domestic banking sectors have significantly increased in recent years in emerging market and developing economies (EMDEs), on average from 8.2 to 11.8 percent of banks' total assets between 2008 and 2016. In oil exporting EMDEs, the rise has been even sharper, banks' holdings of domestic sovereign debt having almost tripled over the 2008-16 period, from 4.2 to 11.7 percent.

These developments have raised concerns for credit to the private sector. Higher banks' holdings of sovereign debt tend to be associated with a lower growth of credit to the private sector, possibly reflecting some crowding out due to financial repression exerted by governments on banks to force or encourage these latter to purchase public securities. The negative correlation between private sector credit and banks' claims on sovereigns can however reflect other non-exclusive factors, including a crowding-out effect of private investment by public investment, ${ }^{1}$ higher interest rates induced by government borrowing reducing demand for credit by the private sector, a lower demand for credit from the private sector in economic downturns, concomitant with higher public financing needs, and a portfolio rebalancing of banks towards safer and more liquid public assets as the quality of private sector loans deteriorates.

Several papers have analyzed the banks-sovereign nexus in advanced economies but empirical analysis of banks' holdings of sovereign debt in EMDEs remains limited. ${ }^{2}$ Yet, banks in EMDEs are playing a key role in the financing of public deficits, as alternative financing options are generally under-developed. Anecdotal evidence further suggests that private sector lending can be materially impacted by increased banks' claims on domestic sovereigns. ${ }^{3}$

\footnotetext{
${ }^{1}$ While in the long term, public capital expenditure may be complementary to private capital by raising the marginal productivity of this latter, in particular thanks to infrastructure (crowding-in effect), in the short term, public investment may reduce private investment by competing for scarce physical and financial resources (crowding-out effect). Larger banks' holdings of government securities could therefore reflect higher public investment and the associated lower investment and demand for credit by the private sector.

${ }^{2}$ Emran and Farazi (2009) document a negative relationship between banks' claims on the government and credit to the private sector for a panel of 60 developing countries but do not explore the possibility of a portfolio rebalancing hypothesis. Gennaioli Martin Rossi (2018) use a sample of 191 countries but focus on the effects of sovereign defaults on the lending activity of banks holding government securities.

${ }^{3}$ In Nigeria, "lending to the private sector [in 2016-17] was largely crowded out by government borrowing" (IMF 2017). In Egypt, "low credit reflects crowding out from public sector borrowing, which pushes interest rates up and reduces incentives to lend to the private sector." (IMF 2015a). In some Arab countries "public banks still dominate the banking sector activities (...), exceeding 70 percent of the share in certain countries (...). [This] hinders competition and leads to an increasing level of credit facilities to public sector, hence, crowding out private lending." (Prasad and others 2016). The crowding out of loans to the private sector by public debt may however not necessarily result from financial repression. It could mirror weak credit market institutions making investment in sovereigns relatively more profitable for banks than credit to the private sector.
} 
This paper investigates the effect of banks' holdings of government debt on private sector credit and banks' profitability in EMDEs. It uses macroeconomic data, given the lack of publicly available bank-level information for this class of countries. Results of the analysis point to a significant negative relationship between banks' holdings of government securities and private sector credit growth in EMDEs that is not explained by a traditional crowding out of private investment by public investment or higher interest rates induced by government borrowing. Whether this negative relationship reflects a crowding out of private sector credit due to regulation, direct control of banks, or moral suasion (the financial repression hypothesis) or a portfolio rebalancing of banks towards safer and more liquid public assets in stress times (the portfolio rebalancing hypothesis) is however a challenging empirical issue, while both hypotheses can be at work simultaneously. ${ }^{4}$ Using the identification strategy employed by Ongena Popov Van Horen (2016) or Dell'Ariccia and others (2018) based on the amount of maturing public debt provides only limited support to the financial repression hypothesis at the macroeconomic level. Conversely, banks are found to increase their holdings of government securities when non-performing loans are higher, in line with the portfolio rebalancing hypothesis. Analysis of the effect of banks' holdings of government debt on banks' profitability further lend support to the portfolio rebalancing hypothesis. Banks' claims on the government have a positive impact on the after-tax return on assets, which is found to be pretty similar to the impact estimated with the pre-tax return on assets, indicating that the tax treatment of public securities cannot explain the positive relationship between government debt holdings and banks' profitability. Importantly, banks' claims on the government do not show any significant relationship with the net interest margin, suggesting that their relationship with banks' profits operates mainly through lower provisions for loan losses.

A growing number of papers document a negative impact of banks' holdings of government debt on lending to the private sector. A first strand of the literature studies the indirect effect of the banks-sovereign nexus on private sector lending through damaged banks' balance sheets in periods of sovereign stress. ${ }^{5} \mathrm{~A}$ second strand analyses the crowding-out effect of private sector credit by lending to the government consecutive to moral suasion. Properly

\footnotetext{
${ }^{4}$ As noted by Becker and Ivashina (2018), financial repression comprises policies used by the government to redirect savings held by domestic financial intermediaries towards the financing of public debt. This can take the form of regulation, direct control of banks, or moral suasion (that is, government pressures on banks to increase holdings of domestic sovereign securities).

${ }^{5}$ Broner and others (2014) argue that purchases of domestic sovereign bonds crowd out bank credit to the private sector because domestic banks find it difficult to obtain credit from abroad at times of sovereign stress while in addition, they absorb a larger share of sovereign issuances. Popov and van Horen (2015) find that banks exposed to stressed euro area sovereign bonds increased lending in the syndicated loan market much less compared to non-exposed banks. Altavilla Pagano Saverio (2016) find that an increase in sovereign credit risk, owing to the exposures of lenders to government debt, has a significant effect on their lending to the private sector in stressed euro area countries. Gennaioli Martin Rossi (2018) find for a sample of 191 countries that banks' holdings of sovereign bonds are associated with a decline of lending during sovereign defaults.
} 
identifying effects from moral suasion is a key issue in these papers as the reduction in credit growth can simply reflect a lower demand for credit from the private sector or a portfolio rebalancing of banks towards safer and more liquid public debt in a riskier environment without any connection to financial repression. Becker and Ivashina (2018) find that many European firms issuing debt switched away from banks' loans into bond financing as European banks were expanding their holdings of domestic sovereign debt between 2007 and 2015. Ongena Popov Van Horen (2016) find that during the euro area sovereign debt crisis, domestic banks, in particular those state-owned or receiving government support, were more likely to purchase domestically-issued sovereign debt than foreign banks in the months when the government had to roll over a relatively large amount of maturing sovereign debt. ${ }^{6}$ These same domestic banks were then granting less credit to households and were doing so at higher interest rates, in the months directly following months with high government refinancing needs. ${ }^{7}$

This paper contributes to the second strand of the literature by using IMF International Financial Statistics (IFS) data available for a large sample of EMDEs. The use of macroeconomic data makes identification of financial repression more difficult than using bank-level data, as done by papers focusing on the euro are crisis, since these latter identify effects from financial repression in specific situations (for domestic banks and/or banks with closer links to the government) which cannot be isolated in a macroeconomic setting. On the other hand, the macroeconomic approach provides an estimate of the macroeconomic effects from financial repression for several countries for which bank-level information is largely incomplete.

The rest of the paper is organized as follows. Section 2 describes the data and provides some descriptive statistics. Section 3 presents results of the econometric estimations of the effect of banks' holdings of government securities on credit growth to the private sector, of the determinants of banks' holdings of government debt, and of the relationship of these latter with banking sector profitability. Section 4 concludes.

\section{Data And Descriptive Statistics}

Data on individual banks' holdings of government debt are in general not publicly available. Some papers (Popov and Van Horen 2015; Becker and Ivashina 2018) use individual banks' holdings of sovereign debt over 2010-2015, collected by the European Banking Authority (EBA) in the context of the European stress tests. Other papers (e.g. Ongena Popov Van

\footnotetext{
${ }^{6}$ The identification strategy employed by the authors is based on the assumption that the amount of maturing public debt is fully exogenous to economic and financial conditions and to banks' demand for domestic sovereign debt. Under the moral suasion hypothesis, banks' claims on the government should be positively related to the need for the government to roll over its debt, to the detriment of credit to the private sector.

${ }^{7}$ Conversely, lending to firms was not affected, probably as moral suasion mainly impacted the types of private lending based on weaker credit relationships (lending to household is often a one-off loan) and which are therefore less costly to cut.
} 
Horen 2016) use data from the ECB's Individual Balance Sheet Statistics covering about 70 percent of the domestic banking sector in Europe since August 2007. Information with longer history and for other countries is however not available. Gennaioli Martin Rossi (2018) consider information from the Bankscope (now Fitch Connect) database but these data do not separate domestic from foreign sovereign bonds, ${ }^{8}$ and more importantly, are relatively scant for most EMDEs. In many EMDEs, bank-level data from Fitch Connect are indeed available for only a few banks and over a very short period.

This paper uses information from the IMF IFS database which provides data on domestic sovereign bonds held by the banking sector and other monetary statistics in virtually all IMF countries since 2001. Information on other macroeconomic variables comes from the WEO database, the GFSR database, and the Global Financial Development Database (see Appendix Table 1 for details). The final sample is composed of an unbalanced panel of around 80 EMDEs over 2001-2016, depending on specifications (Appendix Table 2).

Banking sectors' holdings of government debt, measured as banks' claims on the domestic government as a share of the banking sector's total assets, varies greatly across countries and are in general larger in EMDEs than in AEs (Figure 1). Over 2010-16, banks' claims on the domestic government in EMDEs were on average twice as large as in AEs (10.4 percent versus 5.1 percent of total assets). ${ }^{9}$ Financing options available to sovereigns are less diverse in EMDEs than in AEs while a large share of state-owned banks and banks' greater expectations of special treatment from holding public debt facilitate bank financing of the government in times of fiscal stress (Dell'Ariccia and others 2018). Also, investment opportunities in the private sector are less developed in EMDEs than in AEs, contributing to the relatively larger banks' holdings of government debt in these countries.

\section{Figure 1. Banks' Holdings of Sovereign Debt in AEs and EMDEs, 2010-16 Averages}

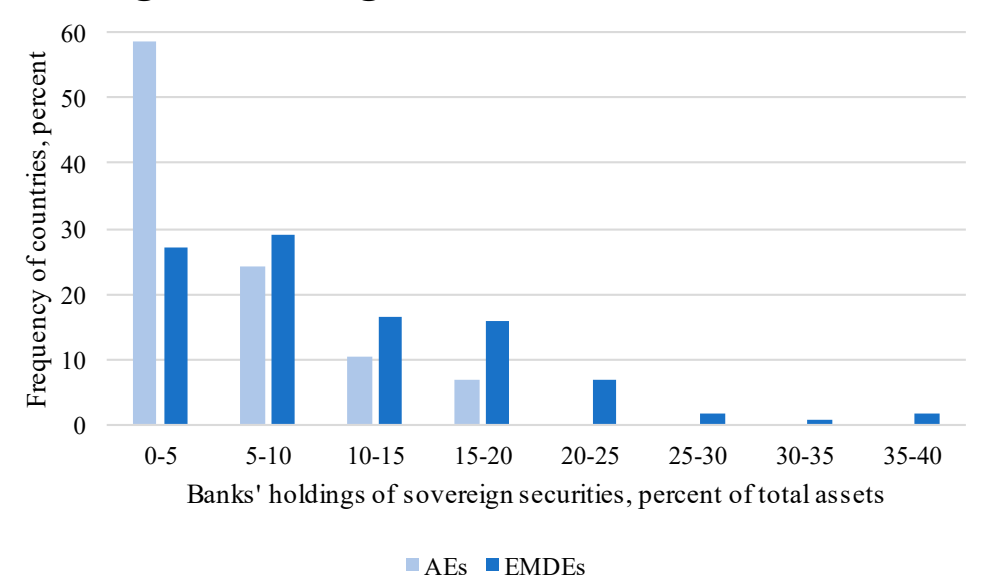

Sources: IMF International Financial Statistics and author's calculations.

\footnotetext{
${ }^{8}$ The authors however document that the bulk of sovereign securities held by banks are actually issued by the domestic government, based on a sub-sample of observations for which more precise information is available.

${ }^{9}$ Using Bankscope data, Dell'Ariccia and others (2018) report that public debt securities as a share of banks' total assets represented 7.8 percent in AEs versus 16.8 percent in EMDEs on average over 2005-14. These numbers are however not comparable to those presented here using IFS information as these are based on a sample of 46 countries and a limited number of banks. Also, Bankscope data include foreign sovereign
} 
In recent years, banks' claims on governments have increased in several economies, especially in sub-Saharan African countries ( 8 countries out of the 20 EMDEs with the largest increases are from sub-Saharan Africa), probably reflecting lower buffers and more limited external financing options of governments in these countries (Figure 2). While public debt may be an important driver of banks' holdings of government securities, the link between the two variables is not particularly strong (Figure 3), highlighting the heterogeneity across countries and over time of the availability of sources of financing of public debt alternative to domestic banking sectors.

\section{Figure 2. Changes in Banks' Holdings of Sovereign Debt in EMDEs (20 Largest Decreases and Increases), 2010-14 to 2015-16 Average, p.p. of Total Assets}

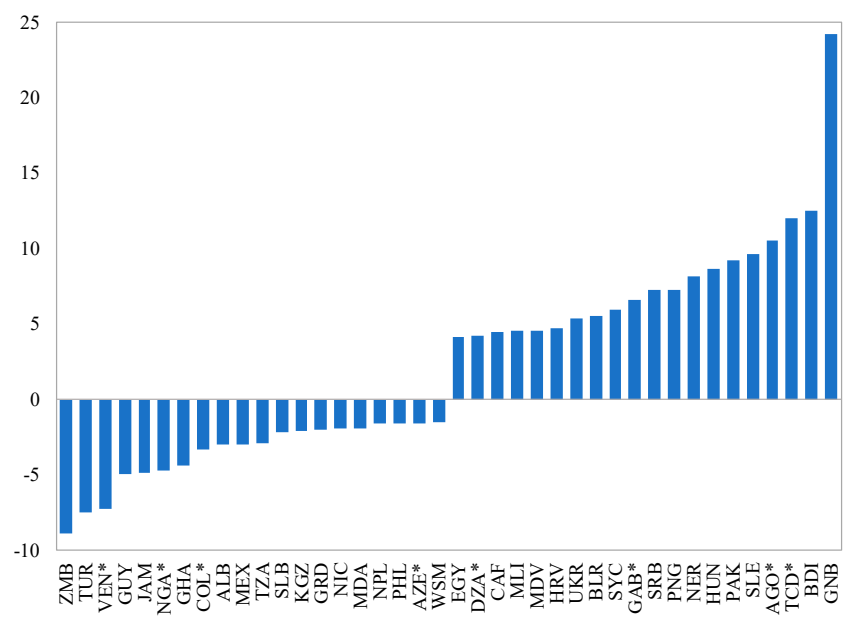

Sources: IMF International Financial Statistics and author's calculations. Notes: * denotes countries with changes from 2010-14 average to 2015 value. Based on a sample of 114 EMDEs, including 38 sub-Saharan African countries.

Figure 3. Changes in Banks' Holdings of Sovereign Debt (p.p. of Total Assets) and in Public Debt (p.p. of GDP), 2010-14 to 2015-16 Average

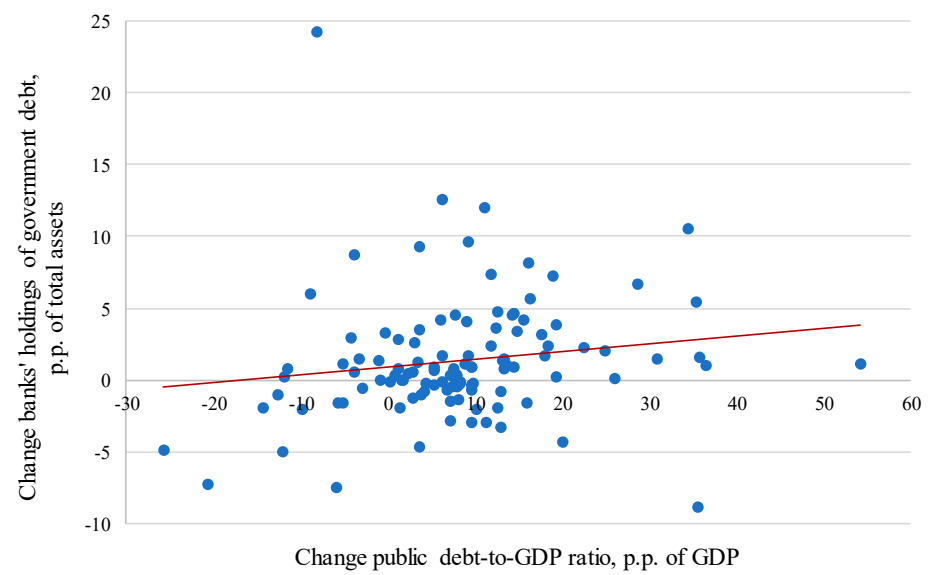

Sources: IMF International Financial Statistics and author's calculations.

securities on top of domestic sovereign debt. A detailed list of holdings of government debt country by country using IFS information back to 1970 is reported in the annex of Dell'Ariccia and others (2018). 
Figure 4. Banks' Holdings of Public Debt as a Share of Total Assets (x-axis, p.p.) and Credit Growth to the Private Sector (y-axis, percent) in Selected Economies

\section{Emerging Market Economies}
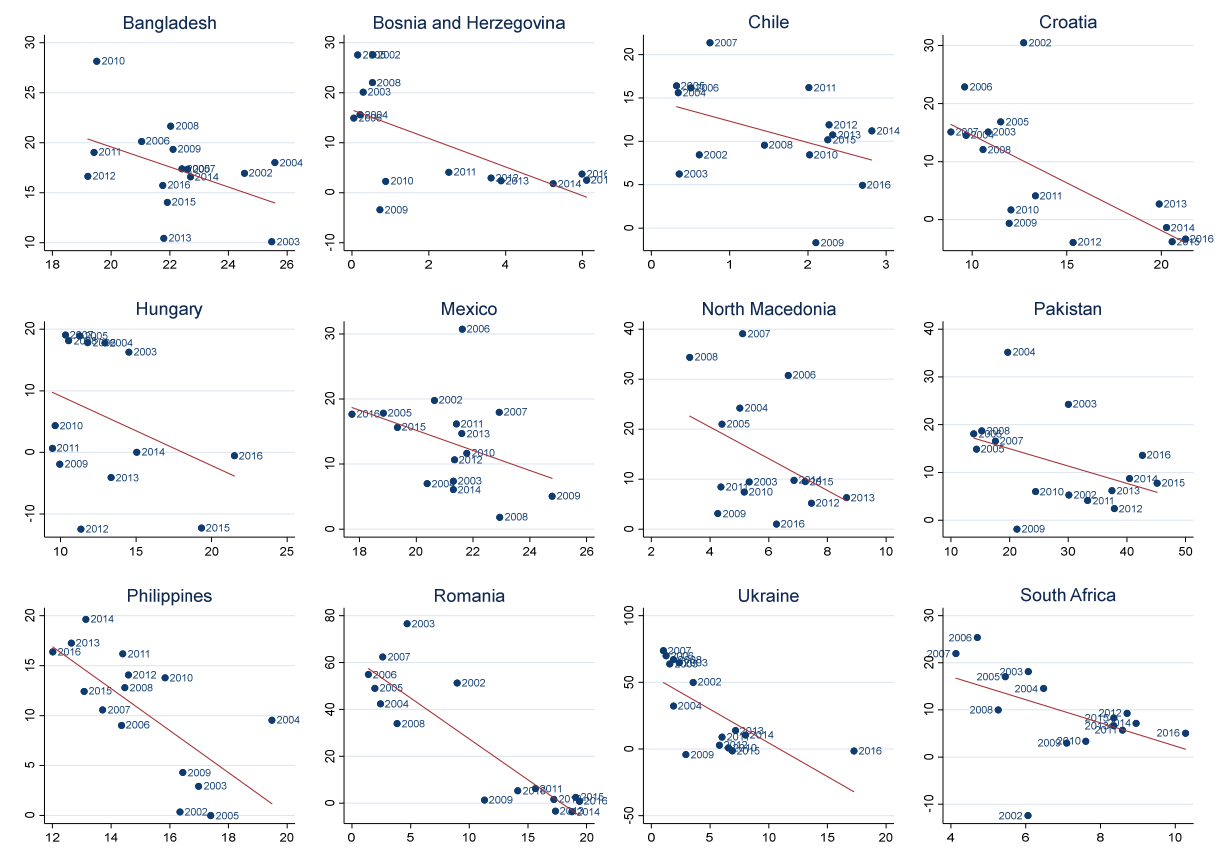

\section{Developing Economies}
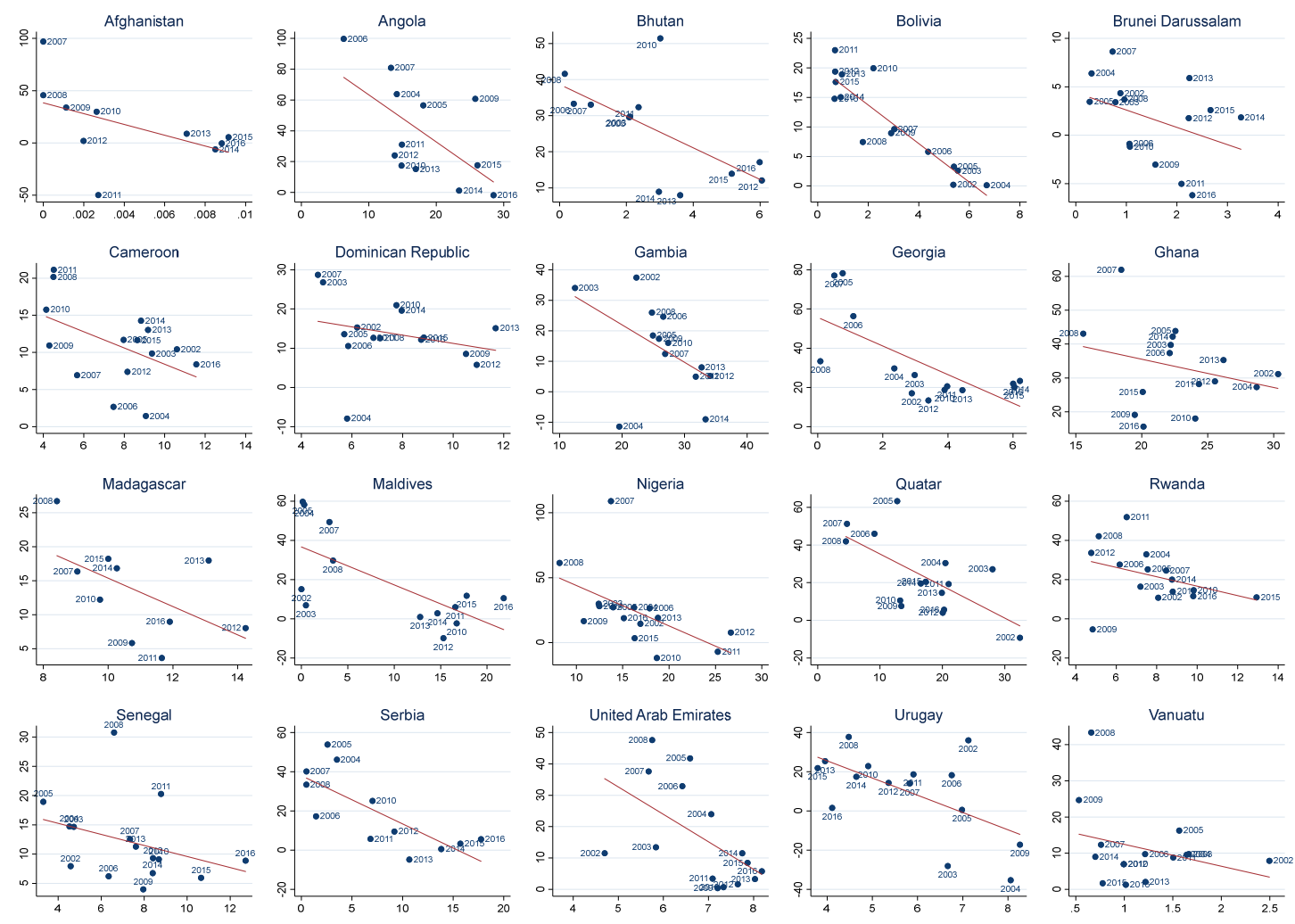

Sources: IMF International Financial Statistics and author's calculations. 
Finally, in line with anecdotal evidence reported in several IMF country reports, many countries show a clear negative relationship between private sector credit growth and banks' holdings of government debt, even without controlling for traditional drivers of credit growth. This negative relationship can be observed in both emerging and developing economies, across various regions (Figure 4, Panels 1 and 2).

The following section assesses the robustness of this relationship based on an econometric analysis of credit growth, controlling for various determinants of credit. Also, the drivers and consequences of banks' holdings of government debt are investigated by looking at the determinants of banks' claims on the government and at the relationship between these latter and banks' profitability.

\section{EMPIRICAL ANALYSIS}

This section presents the empirical methodology and results of regressions for credit growth, banks' holdings of government securities, and banking sector profitability.

\section{A. Credit Growth to the Private Sector}

The relationship between banks' holdings of sovereign debt and private credit growth is estimated using the following panel data equation, controlling for traditional determinants of credit to the private sector (see e.g., Guo and Stepanyan, 2011):

Credit growth $_{i, t}=\alpha_{0}+\alpha_{1}$ Domdep $_{i, t}+\alpha_{2}$ Fordep $_{i, t}+\alpha_{3}\left(\right.$ Credit / Deposits $_{i, t-1}$ $+\alpha_{4}$ Growth $_{i, t-1}+\alpha_{5}$ IR $_{i, t-1}+\alpha_{6}$ Volat $_{i, t-1}+\alpha_{7}$ Inf $_{i, t}+\alpha_{8} \Delta F X_{i, t}+\alpha_{9}$ Banking crisis $_{i, t-1}+\alpha_{10}$ War $_{i, t-1}$

$+\alpha_{11} N P L_{i, t-1}+\alpha_{12}$ ClaimsGvt $_{i, t}+\alpha_{13}$ Pubdebt $_{i, t-1}+\alpha_{14}$ ROA $_{i, t-1}+\alpha_{15}$ Refin $_{i, t-1}$

$+\alpha_{16}$ High maturing debt $_{i, t}+\eta_{i}+\theta_{t}+\varepsilon_{i, t}$,

where:

- Credit growth denotes the annual growth rate of commercial banks' credit to the domestic private sector; ${ }^{10}$

- Domdep is the growth of domestic deposits at commercial banks, weighted by the share of domestic deposits in total credit to the private sector one year ago. It is included to control for the importance of domestic deposits as a funding source. Higher growth of domestic deposits is expected to increase private credit growth;

- Fordep is the growth of foreign deposits, weighted by the share of foreign deposits in total credit to the private sector one year ago. This variable controls for the importance of foreign deposits as a funding source. Higher growth of foreign deposits is also expected to increase private credit growth;

\footnotetext{
${ }^{10}$ Given that credit growth does not show any persistence (as confirmed in unreported regressions), the econometric specification does not include a lagged dependent variable.
} 
- Credit-to-total deposits (i.e. domestic and foreign deposits, excluding liabilities to the central bank), one-year lagged, is used to control for cyclical variations of credit and should be negatively associated with credit growth;"11

- Growth is real GDP growth, one-year lagged, expected to increase credit growth;

- $\quad I R$ is the deposit rate, one-year lagged, used as a proxy for the monetary policy stance, in the absence of a common variable of monetary policy rates in most developing countries. ${ }^{12}$ This variable is expected to impact negatively credit growth;

- Volat is real GDP growth volatility, one-year lagged (based on a GARCH $(1,1)$ measure of real GDP growth), and is expected to decrease credit growth;

- Inf is the consumer price index inflation. Nominal credit growth is mechanically impacted by inflation. As noted by Guo and Stepanyan (2011), a coefficient lower than one would indicate a detrimental impact of inflation on real credit growth;

- $\triangle F X$ is the growth rate of the nominal exchange rate (a higher rate denoting a depreciation of the domestic currency against the U.S. dollar), expected to increase credit growth, especially in countries where foreign currency loans represent a significant portion of private credit, due to valuation effects (Guo and Stepanyan 2011). On the other hand, a sharp depreciation could also be associated with lower credit growth;

- Banking crisis and War are dummy variables taking value one, respectively in years experiencing a crisis in the banking sector and in years experiencing a conflict, and are expected to be negatively related to credit growth;

- $\quad N P L$ denotes non-performing loans as a share of total loans, one year-lagged, and are expected to affect credit growth negatively;

- Claims Gvt denotes commercial banks' claims on the domestic government as a share of banks' total assets. Banks' holdings of domestic government securities are expected to be negatively related to the growth of credit to the private sector; ${ }^{13}$

- Pubdebt the public debt-to-GDP ratio, one-year lagged, should be negatively associated with credit growth, possibly reflecting a crowding-out effect;

- $R O A$, the return on assets after taxes, one year-lagged, is used as a proxy of banks' profitability, and is expected to explain credit growth positively;

\footnotetext{
${ }^{11}$ Results (not reported) are qualitatively similar if the ratio of credit to total deposits enters the regression with a two- or three-year lag.

${ }^{12}$ The deposit rate also offers a better country coverage than the lending rate.

${ }^{13}$ The variable of banks' claims on the government enters the regression contemporaneously as the crowdingout effect of banks' holdings of sovereign debt is likely to be contemporaneous rather than lagged (for a given year, banks choose between lending to the government or to the private sector), especially when using annual data.
} 
- Refin denotes central bank's refinancing operations of commercial banks (as a share of commercial banks' total assets), one-year lagged, used as a proxy of liquidity stress in the banking sector and should be negatively associated with credit growth;

- High maturing debt is a dummy variable taking the value one in years when public debt maturing is above its country-specific median, as defined in Ongena Popov Van Horen (2016). Under the financial repression hypothesis, banks' credit growth to the private sector should be negatively related to the need for the government to refinance its debt, that is decrease in years when the amount of maturing public debt is high. This variable is included without a lag, for the same reason that banks' claims on the government enter the regressions contemporaneously.

$\eta_{i}$ and $\theta_{t}$ denote respectively country and year fixed effects.

Except otherwise indicated, all explanatory variables enter the regressions with a one-year lag to address reverse causality issues and/or because their effects on credit growth are expected to materialize with a lag. ${ }^{14}$

Results of the regressions reported in Table 1 indicate that most variables are significant with the expected sign. Credit growth to the private sector is positively explained by deposit growth and non-resident liability growth (in line with results obtained by Guo and Stepanyan 2011 for emerging economies), and depends negatively on economic volatility, on the public debt-to-GDP ratio - possibly reflecting a crowding-out effect (while the impact of the fiscal deficit, not reported, is found to be nonsignificant), and on the interest rate, proxied by the deposit rate. One-standard deviation increases in real GDP growth volatility, in the public debt ratio, and in the deposit rate are associated the following year with a decrease of credit growth respectively of $2.3,2.9$, and 2.2 percentage points. ${ }^{15}$ The negative effect of nonperforming loans is highly significant and robust across various specifications: a onestandard deviation increase in the NPL ratio translates into a reduction of credit growth of 2.3 percentage points the following year (based on specification (4)).

Importantly, banks' claims on the government are negatively and significantly related to private credit growth, both statistically and economically. On average, a one-standard deviation increase in banks' holdings of government debt is associated with a decrease in private credit growth of 3.2 percentage points (based on specification (4)).

\footnotetext{
${ }^{14}$ Following Guo and Stepanyan (2011), the growth of domestic deposits at commercial banks Domdep and the growth of foreign deposits Fordep, enter the regressions contemporaneously as controls. The consumer price index inflation rate Inf and the growth rate of the nominal exchange rate $\Delta F X$, also enter the regressions contemporaneously but results are anyway qualitatively similar if these variables are considered with a one-year lag.

${ }^{15}$ Results concerning the variable of GDP growth volatility should however be interpreted with caution given the small number of observations used to estimate the GARCH model.
} 
Table 1. Banks' Claims on the Government and Credit Growth to the Private Sector

\begin{tabular}{|c|c|c|c|c|c|c|c|c|c|c|}
\hline & \multicolumn{10}{|c|}{ Dependent variable: Growth rate of banks' credit to the private sector } \\
\hline & (1) & (2) & (3) & (4) & (5) & (6) & (7) & (8) & (9) & $(10)$ \\
\hline Domestic deposits growth, weighted & $\begin{array}{c}0.253^{\star \star \star} \\
(3.37)\end{array}$ & $\begin{array}{c}0.247^{* * *} \\
(3.23)\end{array}$ & $\begin{array}{c}0.262^{\star \star \star} \\
(3.22)\end{array}$ & $\begin{array}{c}0.234^{\star \star \star} \\
(2.90)\end{array}$ & $\begin{array}{c}0.231^{* \star} \\
(2.52)\end{array}$ & $\begin{array}{c}0.244^{\star \star \star} \\
(3.00)\end{array}$ & $\begin{array}{c}0.235^{\star \star \star} \\
(2.96)\end{array}$ & $\begin{array}{c}0.233^{\star * \star} \\
(2.87)\end{array}$ & $\begin{array}{c}0.176^{* \star} \\
(2.04)\end{array}$ & $\begin{array}{l}0.175^{\star *} \\
(2.04)\end{array}$ \\
\hline Foreign deposits growth, weighted & $\begin{array}{c}0.505^{\star *} \\
(2.45)\end{array}$ & $\begin{array}{l}0.509^{\star *} \\
(2.54)\end{array}$ & $\begin{array}{c}0.509^{* *} \\
(2.48)\end{array}$ & $\begin{array}{c}0.512^{* *} \\
(2.42)\end{array}$ & $\begin{array}{c}0.490^{* *} \\
(2.28)\end{array}$ & $\begin{array}{c}0.524^{* *} \\
(2.46)\end{array}$ & $\begin{array}{c}0.525^{* *} \\
(2.46)\end{array}$ & $\begin{array}{l}0.514^{* *} \\
(2.37)\end{array}$ & $\begin{array}{c}0.504^{* *} \\
(2.33)\end{array}$ & $\begin{array}{l}0.508^{* *} \\
(2.39)\end{array}$ \\
\hline Credit to total deposits, lagged & $\begin{array}{c}-0.368^{* * \star} \\
(-4.33)\end{array}$ & $\begin{array}{c}-0.367^{\star * *} \\
(-4.22)\end{array}$ & $\begin{array}{c}-0.371^{* * *} \\
(-4.16)\end{array}$ & $\begin{array}{c}-0.322^{\star \star *} \\
(-3.98)\end{array}$ & $\begin{array}{c}-0.348^{\star \star *} \\
(-3.79)\end{array}$ & $\begin{array}{c}-0.311^{* * *} \\
(-3.90)\end{array}$ & $\begin{array}{c}-0.293^{\star * *} \\
(-3.71)\end{array}$ & $\begin{array}{c}-0.273^{\star * *} \\
(-3.67)\end{array}$ & $\begin{array}{c}-0.344^{* \star \star} \\
(-3.80)\end{array}$ & $\begin{array}{c}-0.344^{* * *} \\
(-3.75)\end{array}$ \\
\hline Real GDP growth, lagged & $\begin{array}{l}-0.029 \\
(-0.24)\end{array}$ & $\begin{array}{l}-0.078 \\
(-0.68)\end{array}$ & $\begin{array}{l}-0.048 \\
(-0.45)\end{array}$ & $\begin{array}{l}-0.071 \\
(-0.66)\end{array}$ & $\begin{array}{l}-0.115 \\
(-1.02)\end{array}$ & $\begin{array}{l}-0.065 \\
(-0.61)\end{array}$ & $\begin{array}{l}-0.056 \\
(-0.54)\end{array}$ & $\begin{array}{l}-0.058 \\
(-0.57)\end{array}$ & $\begin{array}{l}-0.065 \\
(-0.58)\end{array}$ & $\begin{array}{l}-0.106 \\
(-1.00)\end{array}$ \\
\hline Deposit rate, lagged & $\begin{array}{l}-0.401^{*} \\
(-1.93)\end{array}$ & $\begin{array}{l}-0.421^{*} \\
(-1.83)\end{array}$ & $\begin{array}{c}-0.603^{* * *} \\
(-2.69)\end{array}$ & $\begin{array}{c}-0.441^{* *} \\
(-2.08)\end{array}$ & $\begin{array}{l}-0.378 \\
(-1.63)\end{array}$ & $\begin{array}{c}-0.458^{* *} \\
(-2.16)\end{array}$ & $\begin{array}{c}-0.488^{* *} \\
(-2.29)\end{array}$ & $\begin{array}{c}-0.482^{* *} \\
(-2.41)\end{array}$ & $\begin{array}{c}-0.599^{* *} \\
(-2.60)\end{array}$ & $\begin{array}{l}-0.484^{*} \\
(-1.94)\end{array}$ \\
\hline Real GDP growth volatility, lagged & $\begin{array}{c}-0.617^{\star *} \\
(-2.25)\end{array}$ & $\begin{array}{c}-0.651^{\star *} \\
(-2.48)\end{array}$ & $\begin{array}{c}-0.807^{\star *} \\
(-2.45)\end{array}$ & $\begin{array}{c}-0.775^{\star *} \\
(-2.27)\end{array}$ & $\begin{array}{c}-0.799^{\star *} \\
(-2.05)\end{array}$ & $\begin{array}{c}-0.771^{* *} \\
(-2.22)\end{array}$ & $\begin{array}{c}-0.746^{* *} \\
(-2.15)\end{array}$ & $\begin{array}{c}-0.630^{*} \\
(-1.76)\end{array}$ & $\begin{array}{c}-0.763^{* *} \\
(-2.29)\end{array}$ & $\begin{array}{c}-0.839^{* * *} \\
(-2.67)\end{array}$ \\
\hline Inflation & $\begin{array}{c}0.260^{* *} \\
(2.05)\end{array}$ & $\begin{array}{l}0.297^{* *} \\
(2.32)\end{array}$ & $\begin{array}{l}0.304^{* *} \\
(2.54)\end{array}$ & $\begin{array}{l}0.140 \\
(0.96)\end{array}$ & $\begin{array}{l}0.113 \\
(0.73)\end{array}$ & $\begin{array}{l}0.146 \\
(1.00)\end{array}$ & $\begin{array}{l}0.167 \\
(1.17)\end{array}$ & $\begin{array}{l}0.170 \\
(1.16)\end{array}$ & $\begin{array}{l}0.034 \\
(0.17)\end{array}$ & $\begin{array}{l}0.145 \\
(0.65)\end{array}$ \\
\hline Change in average exchange rate & $\begin{array}{l}-0.096 \\
(-1.47)\end{array}$ & $\begin{array}{l}-0.078 \\
(-1.28)\end{array}$ & $\begin{array}{l}-0.080 \\
(-1.38)\end{array}$ & $\begin{array}{l}-0.038 \\
(-0.62)\end{array}$ & $\begin{array}{l}-0.024 \\
(-0.37)\end{array}$ & $\begin{array}{l}-0.035 \\
(-0.57)\end{array}$ & $\begin{array}{l}-0.034 \\
(-0.55)\end{array}$ & $\begin{array}{l}-0.043 \\
(-0.70)\end{array}$ & $\begin{array}{l}-0.081 \\
(-1.15)\end{array}$ & $\begin{array}{l}-0.054 \\
(-0.85)\end{array}$ \\
\hline Banking crisis dummy, lagged & $\begin{array}{c}-7.807^{\star *} \\
(-2.32)\end{array}$ & $\begin{array}{c}-7.148^{\star *} \\
(-2.07)\end{array}$ & $\begin{array}{c}-6.726^{*} \\
(-1.83)\end{array}$ & $\begin{array}{l}-5.594 \\
(-1.48)\end{array}$ & $\begin{array}{c}-7.024^{*} \\
(-1.86)\end{array}$ & $\begin{array}{l}-5.944 \\
(-1.53)\end{array}$ & $\begin{array}{l}-6.365 \\
(-1.54)\end{array}$ & $\begin{array}{c}-7.358^{*} \\
(-1.75)\end{array}$ & $\begin{array}{c}-9.925^{*} \\
(-1.97)\end{array}$ & $\begin{array}{l}-8.495 \\
(-1.62)\end{array}$ \\
\hline War dummy, lagged & $\begin{array}{c}-6.559^{* *} \\
(-2.44)\end{array}$ & $\begin{array}{c}-6.387^{* * *} \\
(-2.69)\end{array}$ & $\begin{array}{c}-6.459^{* * *} \\
(-2.68)\end{array}$ & $\begin{array}{c}-5.544^{* *} \\
(-2.40)\end{array}$ & $\begin{array}{c}-5.629^{* *} \\
(-2.36)\end{array}$ & $\begin{array}{c}-5.845^{\star *} \\
(-2.63)\end{array}$ & $\begin{array}{c}-6.324^{* * *} \\
(-3.14)\end{array}$ & $\begin{array}{c}-5.749^{* * *} \\
(-2.73)\end{array}$ & $\begin{array}{c}-6.834^{*} \\
(-1.83)\end{array}$ & $\begin{array}{c}-7.562^{* *} \\
(-2.12)\end{array}$ \\
\hline NPL ratio, lagged & $\begin{array}{c}-0.439^{* \star *} \\
(-3.22)\end{array}$ & $\begin{array}{c}-0.345^{\star *} \\
(-2.26)\end{array}$ & $\begin{array}{c}-0.349^{* *} \\
(-2.30)\end{array}$ & $\begin{array}{c}-0.349^{* *} \\
(-2.39)\end{array}$ & $\begin{array}{l}-0.235^{\star} \\
(-1.86)\end{array}$ & $\begin{array}{c}-0.350^{* *} \\
(-2.41)\end{array}$ & $\begin{array}{c}-0.348^{* *} \\
(-2.43)\end{array}$ & $\begin{array}{c}-0.320^{* *} \\
(-2.19)\end{array}$ & $\begin{array}{c}-0.715^{* \star *} \\
(-4.16)\end{array}$ & $\begin{array}{c}-0.629^{* * *} \\
(-3.61)\end{array}$ \\
\hline Banks' claims on gvt to total assets & $\begin{array}{c}-0.463^{* * *} \\
(-3.56)\end{array}$ & $\begin{array}{c}-0.395^{\star * *} \\
(-3.01)\end{array}$ & $\begin{array}{c}-0.380^{* * *} \\
(-2.82)\end{array}$ & $\begin{array}{c}-0.353^{* * *} \\
(-2.69)\end{array}$ & $\begin{array}{c}-0.459^{* \star *} \\
(-3.55)\end{array}$ & & & & & \\
\hline Public debt-to-GDP ratio, lagged & & $\begin{array}{c}-0.134^{\star *} \\
(-2.57)\end{array}$ & $\begin{array}{c}-0.133^{* * *} \\
(-2.64)\end{array}$ & $\begin{array}{c}-0.131^{* *} \\
(-2.42)\end{array}$ & $\begin{array}{l}-0.113^{*} \\
(-1.95)\end{array}$ & $\begin{array}{c}-0.135^{* *} \\
(-2.49)\end{array}$ & $\begin{array}{c}-0.132^{* *} \\
(-2.47)\end{array}$ & $\begin{array}{c}-0.154^{\star * *} \\
(-2.82)\end{array}$ & & $\begin{array}{c}-0.158^{* * *} \\
(-3.02)\end{array}$ \\
\hline Banks' return on assets, lagged & & & $\begin{array}{l}0.139 \\
(0.17)\end{array}$ & $\begin{array}{l}0.841 \\
(1.37)\end{array}$ & $\begin{array}{l}0.850 \\
(1.32)\end{array}$ & $\begin{array}{l}0.853 \\
(1.38)\end{array}$ & $\begin{array}{l}0.858 \\
(1.40)\end{array}$ & $\begin{array}{l}0.945 \\
(1.52)\end{array}$ & $\begin{array}{l}0.149 \\
(0.25)\end{array}$ & $\begin{array}{l}0.229 \\
(0.37)\end{array}$ \\
\hline Central bank refin. to total assets, lagged & & & & $\begin{array}{l}-0.505 \\
(-1.64)\end{array}$ & $\begin{array}{l}-0.415 \\
(-1.35)\end{array}$ & $\begin{array}{l}-0.503 \\
(-1.62)\end{array}$ & $\begin{array}{l}-0.438 \\
(-1.42)\end{array}$ & $\begin{array}{l}-0.441 \\
(-1.37)\end{array}$ & $\begin{array}{c}-0.795^{*} \\
(-1.71)\end{array}$ & $\begin{array}{l}-0.696 \\
(-1.48)\end{array}$ \\
\hline Public investment-to-GDP ratio, lagged & & & & & $\begin{array}{l}0.248 \\
(1.15)\end{array}$ & & & & & \\
\hline Banks' claims on gvt to lagged total assets & & & & & & $\begin{array}{c}-0.237^{* *} \\
(-2.29)\end{array}$ & & & & \\
\hline Banks' claims on gvt to lagged GDP & & & & & & & $\begin{array}{l}-0.257^{*} \\
(-1.80)\end{array}$ & & & \\
\hline Growth rate of banks' claims on gvt & & & & & & & & $\begin{array}{c}-0.039^{* * *} \\
(-3.18)\end{array}$ & & \\
\hline High maturing public debt dummy & & & & & & & & & $\begin{array}{c}-2.111^{*} \\
(-1.85)\end{array}$ & $\begin{array}{l}-1.695 \\
(-1.52)\end{array}$ \\
\hline Country fixed effects & Yes & Yes & Yes & Yes & Yes & Yes & Yes & Yes & Yes & Yes \\
\hline Year fixed effects & Yes & Yes & Yes & Yes & Yes & Yes & Yes & Yes & Yes & Yes \\
\hline Observations & 920 & 911 & 874 & 817 & 697 & 817 & 817 & 816 & 695 & 695 \\
\hline Number of countries & 88 & 87 & 85 & 83 & 70 & 83 & 83 & 82 & 79 & 79 \\
\hline Adjusted R-squared & 0.535 & 0.540 & 0.541 & 0.528 & 0.511 & 0.525 & 0.523 & 0.528 & 0.539 & 0.546 \\
\hline
\end{tabular}


This negative relationship could reflect a traditional crowding-out effect of private investment by public investment (Aschauer 1989), without any direct connection to financial repression or banks' portfolio rebalancing. ${ }^{16}$ Results are however robust to controlling for public investment as a share of GDP. The estimated coefficient of the public investment ratio is never significant (whether the variable enters the regression in level or in first difference, and contemporaneously or with a one-year lag) while the coefficient on banks' holdings of government securities remains highly significant (column (5)). Likewise, an explanation based on a crowding out via higher interest rates is ruled out as results are robust to controlling for interest rates.

Because part of the relationship between banks' claims on the government and private credit growth may reflect a denominator effect (as total assets include credit to the private sector), alternative specifications consider banks' holdings of sovereign securities expressed as a share of lagged total assets or as a share of lagged nominal GDP (columns (6) and (7)), or the relationship with the growth rate of banks' claims on the government (column (8)). Results are qualitatively similar: a one-standard deviation increase in banks' claims on the government as a share of lagged total assets or as a share of lagged GDP is associated with a decrease of credit growth of 2.5 and 2.3 percentage points, respectively, while the relationship with the growth rate of claims on the government is statistically highly significant, although it is economically weaker than the one related to the ratio of banks' holdings of government debt to total assets or GDP (a one-standard deviation increase in the growth rate of banks' claims on the government is associated with a 1.4-percentage point decrease in credit growth).

Overall, the regressions indicate the presence of a significant negative relationship between credit growth to the private sector and banks' claims on the government, which is robust to the inclusion of major determinants of credit. This negative relationship, however, does not necessarily reflect a crowding-out effect of government financing on private sector credit (the financial repression hypothesis) insofar as banks may rebalance their portfolio towards safer and more liquid public assets when the quality of loans to the private sector deteriorates (the portfolio rebalancing hypothesis).

To investigate the relative importance of the portfolio rebalancing and of the financial repression hypotheses, additional regressions include a dummy variable taking the value one in years when the amount of public debt maturing (as a share of GDP) is above its countryspecific median. As highlighted by Ongena Popov Van Horen (2016), while public debt tends to be endogenous to the business cycle, the amount of maturing debt is fully exogenous to economic and financial conditions and to banks' demand for domestic sovereign debt, since it is pre-determined, being the outcome of choices made many years ago by previous governments.

Under the financial repression hypothesis, banks' claims on the government should be positively related to the need for the government to refinance its debt to the detriment of

\footnotetext{
${ }^{16}$ Higher public investment can reduce private investment by increasing interest rates or macroeconomic instability when it is financed through an unsustainable accumulation of debt. While these effects are already controlled for in the regressions (through the variables of interest rate, inflation, GDP growth volatility, and public debt), other effects, like competition between public and private sectors for the same scarce physical resources may also be at work.
} 
credit to the private sector. Credit growth to the private sector is therefore expected to decrease in years when the amount of maturing public debt is relatively high, as shown by Ongena Popov Van Horen (2016) for a sample of European banks. Results presented in columns (9) and (10) however provide weak support for the financial repression hypothesis. The coefficient on the high public maturing debt dummy variable is significantly negative in specification (9) but is no more significant at conventional levels when controlling for the public debt-to-GDP ratio one year before (column (10)). Conversely, the effect of the lagged NPL ratio remains highly significant statistically and economically.

The next sub-section further investigates the relevance of the financial repression and of the portfolio rebalancing hypotheses by analyzing the determinants of banks' claims on the government.

\section{B. Banks' Claims on the Government}

Banks' holdings of domestic government securities are explained by the following specification:

$$
\begin{aligned}
& \text { ClaimsGvt }_{i, t}=\beta_{0}+\beta_{1} \text { ClaimsGvt }_{i, t-1}+\beta_{2} \text { Growth }_{i, t-1}+\beta_{3} \text { Volat }_{i, t-1}+\beta_{4}\left({\text { Credit } / \text { GDP })_{i, t-1}}\right. \\
& +\beta_{5} \text { Sovereign crisis }_{i, t}+\beta_{6} \operatorname{Inf}_{i, t-1}+\beta_{7} \Delta F X_{i, t-1}+\beta_{8} \text { IR }_{i, t-1}+\beta_{9} \text { Pubdebt }_{i, t-1}+\beta_{10} \text { Fiscal stress }_{i, t} \\
& +\beta_{11} \text { High maturing debt }_{i, t}+\beta_{12} N P L_{i, t-1}+\beta_{13} \text { Refin }_{i, t-1}+\eta_{i}+\theta_{t}+\varepsilon_{i, t}
\end{aligned}
$$

where Sovereign crisis and Fiscal stress are dummy variables taking the value one, respectively in years experiencing a sovereign crisis and in years when the public deficit increases by more than its country-specific standard deviation. The other variables are the same as those used in the credit growth regressions of sub-section A.

Banks are more likely to increase their holdings of government debt when the economic environment deteriorates, as suggested by the portfolio rebalancing hypothesis. GDP growth volatility, inflation (a proxy for economic uncertainty), and NPLs are therefore expected to be positively related to banks' claims on the government while real GDP growth should have a negative impact. The interest rate, proxied by the deposit rate, should explain positively banks' holdings of government debt while central bank refinancing, a proxy of liquidity stress, is expected to have a negative impact on banks' public debt purchases. ${ }^{17}$ The credit-toGDP ratio is expected to explain banks' holdings of government securities negatively, in line with results of Gennaioli Martin Rossi (2018) and Dell'Ariccia and others (2018), as the

\footnotetext{
${ }^{17}$ In some cases, central bank refinancing may however be positively related to banks' holdings of government securities as the central bank may offer liquidity to banks with the objective that these later purchase public securities, a form of indirect monetization of public debt. This practice has been observed in several subSaharan African economies in recent years. In the case of WAEMU for instance, banks' demand for government securities varied proportionally with central bank refinancing. "Commercial banks expanded their holdings of government securities from 17.7 percent to 22.0 percent of total assets between 2011 and 2014 -a similar magnitude to the increase in their stock of outstanding borrowing from the BCEAO (from 4.3 percent to 9.0 percent of total assets)" (IMF 2015b). "In 2015-16, when the refinancing was relatively easily available, government debt issuances were typically oversubscribed in the regional debt market dominated by banks. This changed after the BCEAO policy tightening." (IMF 2018).
} 
demand for public securities to store liquidity should be higher in less financially-developed economies.

Public debt to GDP and fiscal stress are expected to explain banks' holdings of government debt positively, reflecting higher public financing needs. These two variables are however endogenous to the business cycle and therefore do not allow to distinguish between the financial repression and the portfolio rebalancing hypotheses. ${ }^{18}$

Conversely, the amount of maturing debt is fully exogenous to economic and financial conditions and to banks' demand for domestic sovereign debt, since it is pre-determined, being the outcome of choices made many years ago by previous governments, as noted by Ongena Popov Van Horen (2016). Under the financial repression hypothesis, banks' claims on the government should be positively related to the need for the government to refinance its debt, that is increase in years when the amount of maturing public debt is high. On the other hand, the portfolio rebalancing hypothesis predicts that banks' holdings of government securities should mainly depend on the business cycle, especially on the quality of loans to the private sector, as reflected by NPLs. Both hypotheses can of course be at work simultaneously, and the regressions analysis can inform on the relative importance of each of them.

Results of the regressions are reported in Table 2. ${ }^{19}$ As shown in columns (1) to (3), banks' claims on the government increase in years when governments have to roll over a relatively large amount of maturing sovereign debt, while NPLs do not have any significant effect. This result can at first sight be interpreted as supportive of the financial repression hypothesis against the portfolio rebalancing hypothesis. Given that the ratio of banks' claims on the government to total assets is a priori persistent, regressions should however include a lagged dependent variable. As expected, this variable is highly significant (regressions (4) to (6)), but the coefficient on the high maturing public debt dummy variable then becomes negative and nonsignificant while the NPL ratio turns significant with the expected positive sign. These results are robust to using different estimation techniques including OLS (column (4)), Bruno's (2005) correction for Nickell (1981) bias (column (5)), or a system GMM specification (column (6)). ${ }^{20} \mathrm{~A}$ one-standard deviation increase in the NPL ratio translates the following year into a 0.8 to 1 percentage point increase in banks' claims on the government, depending on specifications.

\footnotetext{
${ }^{18}$ As the economy deteriorates, banks may rebalance their portfolio towards safer, more liquid public assets while at the same time, governments may be more likely to exert moral suasion on banks to buy public securities given higher financing needs.

${ }^{19}$ All explanatory variables (with the exception of the dummies for sovereign crisis, fiscal stress, and high maturing debt) are lagged by one year, following Gennaioli Martin Rossi (2018).

${ }^{20}$ System GMM regression is performed using the two-step procedure with the Windmeijer's finite-sample correction. The validity of the instruments is tested using the Hansen test, with the number of instruments being lower than the number of countries to limit a weakening of the Hansen test, as suggested by Roodman (2009). The absence of serial correlation of residuals is tested using the $\operatorname{AR}(2)$ test while in all regressions, the AR(1) test is rejected, suggesting, as expected, a first-order serial correlation of the differenced error term.
} 
Table 2. Determinants of Banks' Holdings of Government Debt

\begin{tabular}{|c|c|c|c|c|c|c|c|c|c|}
\hline \multirow[t]{2}{*}{ Dependent variable: } & \multicolumn{6}{|c|}{ Banks' claims on gvt to total assets } & \multicolumn{3}{|c|}{ Growth rate of banks' claims on gvt } \\
\hline & $\begin{array}{l}\text { OLS } \\
(1)\end{array}$ & $\begin{array}{l}\text { OLS } \\
(2)\end{array}$ & $\begin{array}{l}\text { OLS } \\
(3)\end{array}$ & $\begin{array}{l}\text { OLS } \\
(4)\end{array}$ & $\begin{array}{c}\text { Bruno } \\
(5) \\
\end{array}$ & $\begin{array}{c}\text { Sys GMM } \\
(6)\end{array}$ & $\begin{array}{l}\text { OLS } \\
(7)\end{array}$ & $\begin{array}{l}\text { OLS } \\
(8)\end{array}$ & $\begin{array}{l}\text { OLS } \\
(9)\end{array}$ \\
\hline Banks' claims on gvt to total assets, lagged & & & & $\begin{array}{c}0.768^{* * *} \\
(23.16)\end{array}$ & $\begin{array}{c}0.897^{* * *} \\
(35.09)\end{array}$ & $\begin{array}{c}0.884^{* * *} \\
(8.89)\end{array}$ & & $\begin{array}{c}-1.852^{\star * *} \\
(-3.83)\end{array}$ & $\begin{array}{c}-1.787^{\star * *} \\
(-4.26)\end{array}$ \\
\hline Real GDP growth, lagged & $\begin{array}{c}-0.105^{\star * *} \\
(-2.74)\end{array}$ & $\begin{array}{l}-0.056 \\
(-1.22)\end{array}$ & $\begin{array}{l}-0.063 \\
(-1.32)\end{array}$ & $\begin{array}{l}-0.006 \\
(-0.14)\end{array}$ & $\begin{array}{l}0.001 \\
(0.04)\end{array}$ & $\begin{array}{l}0.027 \\
(0.17)\end{array}$ & $\begin{array}{l}-0.207 \\
(-0.38)\end{array}$ & $\begin{array}{l}-0.350 \\
(-0.69)\end{array}$ & $\begin{array}{l}-0.586 \\
(-1.21)\end{array}$ \\
\hline Real GDP growth volatility, lagged & $\begin{array}{l}-0.097 \\
(-0.99)\end{array}$ & $\begin{array}{l}-0.128 \\
(-0.78)\end{array}$ & $\begin{array}{l}-0.131 \\
(-0.76)\end{array}$ & $\begin{array}{l}0.075 \\
(1.23)\end{array}$ & $\begin{array}{c}0.108^{\star *} \\
(2.09)\end{array}$ & $\begin{array}{l}0.228 \\
(1.44)\end{array}$ & $\begin{array}{c}1.870^{\star *} \\
(2.08)\end{array}$ & $\begin{array}{l}1.474^{*} \\
(1.82)\end{array}$ & $\begin{array}{l}0.711 \\
(0.89)\end{array}$ \\
\hline Credit-to-GDP ratio, lagged & $\begin{array}{c}-0.165^{\star \star *} \\
(-3.26)\end{array}$ & $\begin{array}{c}-0.236^{\star \star \star} \\
(-3.76)\end{array}$ & $\begin{array}{c}-0.239^{\star \star *} \\
(-3.66)\end{array}$ & $\begin{array}{c}-0.032^{*} \\
(-1.79)\end{array}$ & $\begin{array}{l}-0.006 \\
(-0.40)\end{array}$ & $\begin{array}{l}0.023 \\
(0.72)\end{array}$ & $\begin{array}{l}0.321 \\
(1.47)\end{array}$ & $\begin{array}{l}-0.175 \\
(-0.70)\end{array}$ & $\begin{array}{l}-0.219 \\
(-0.91)\end{array}$ \\
\hline Sovereign crisis dummy & $\begin{array}{l}-1.237 \\
(-1.52)\end{array}$ & $\begin{array}{c}-2.275^{\star \star} \\
(-2.03)\end{array}$ & $\begin{array}{c}-3.115^{\star *} \\
(-2.30)\end{array}$ & $\begin{array}{c}-2.429^{\star \star \star} \\
(-3.71)\end{array}$ & $\begin{array}{c}-2.352^{\star \star} \\
(-2.24)\end{array}$ & $\begin{array}{l}-1.543 \\
(-0.42)\end{array}$ & $\begin{array}{c}-33.493^{\star * *} \\
(-3.17)\end{array}$ & $\begin{array}{c}-35.741^{* * *} \\
(-3.12)\end{array}$ & $\begin{array}{c}-27.926^{\star \star *} \\
(-2.99)\end{array}$ \\
\hline Inflation, lagged & $\begin{array}{c}-0.085^{*} \\
(-1.70)\end{array}$ & $\begin{array}{l}-0.063 \\
(-1.05)\end{array}$ & $\begin{array}{l}-0.059 \\
(-0.95)\end{array}$ & $\begin{array}{l}0.071^{*} \\
(1.89)\end{array}$ & $\begin{array}{c}0.082^{\star \star *} \\
(2.79)\end{array}$ & $\begin{array}{c}0.274^{\star \star} \\
(2.53)\end{array}$ & $\begin{array}{c}1.829^{* * *} \\
(3.85)\end{array}$ & $\begin{array}{c}1.548^{\star \star \star} \\
(2.99)\end{array}$ & $\begin{array}{l}1.349^{\star *} \\
(2.15)\end{array}$ \\
\hline Change in average exchange rate, lagged & $\begin{array}{l}-0.011 \\
(-0.47)\end{array}$ & $\begin{array}{l}-0.009 \\
(-0.47)\end{array}$ & $\begin{array}{l}-0.011 \\
(-0.54)\end{array}$ & $\begin{array}{l}0.001 \\
(0.07)\end{array}$ & $\begin{array}{l}0.003 \\
(0.23)\end{array}$ & $\begin{array}{c}-0.097^{\star *} \\
(-2.07)\end{array}$ & $\begin{array}{l}-0.171 \\
(-0.94)\end{array}$ & $\begin{array}{l}-0.201 \\
(-1.10)\end{array}$ & $\begin{array}{l}-0.071 \\
(-0.37)\end{array}$ \\
\hline Deposit rate, lagged & $\begin{array}{c}0.317^{* *} \\
(2.34)\end{array}$ & $\begin{array}{c}0.322^{\star \star} \\
(2.26)\end{array}$ & $\begin{array}{c}0.315^{\star *} \\
(2.27)\end{array}$ & $\begin{array}{c}0.141^{\text {** }} \\
(2.64)\end{array}$ & $\begin{array}{c}0.097^{\star \star} \\
(2.18)\end{array}$ & $\begin{array}{l}-0.158^{*} \\
(-1.76)\end{array}$ & $\begin{array}{l}0.487 \\
(0.79)\end{array}$ & $\begin{array}{l}0.864 \\
(1.37)\end{array}$ & $\begin{array}{l}0.904 \\
(1.35)\end{array}$ \\
\hline Public debt-to-GDP ratio, lagged & $\begin{array}{l}0.019 \\
(1.10)\end{array}$ & $\begin{array}{c}0.061^{\star * *} \\
(3.19)\end{array}$ & $\begin{array}{c}0.064^{* * *} \\
(3.09)\end{array}$ & $\begin{array}{l}-0.016 \\
(-1.60)\end{array}$ & $\begin{array}{c}-0.027^{\star \star \star} \\
(-2.74)\end{array}$ & $\begin{array}{l}-0.010 \\
(-0.31)\end{array}$ & $\begin{array}{c}-0.346^{\star \star} \\
(-2.14)\end{array}$ & $\begin{array}{l}-0.147 \\
(-0.97)\end{array}$ & $\begin{array}{l}-0.170 \\
(-1.21)\end{array}$ \\
\hline Fiscal stress dummy & $\begin{array}{c}0.795^{\star \star} \\
(2.39)\end{array}$ & $\begin{array}{c}1.083^{\star \star \star} \\
(2.84)\end{array}$ & $\begin{array}{c}1.118^{\star * *} \\
(2.93)\end{array}$ & $\begin{array}{c}0.702^{* \star \star} \\
(3.30)\end{array}$ & $\begin{array}{c}0.671^{\star \star \star *} \\
(2.90)\end{array}$ & $\begin{array}{l}2.805 \\
(1.64)\end{array}$ & $\begin{array}{c}16.554^{\star \star \star} \\
(3.62)\end{array}$ & $\begin{array}{c}17.476^{\star \star \star} \\
(3.80)\end{array}$ & $\begin{array}{c}17.247^{\star \star \star} \\
(3.61)\end{array}$ \\
\hline High maturing public debt dummy & $\begin{array}{c}0.762^{\star *} \\
(2.47)\end{array}$ & $\begin{array}{c}0.790^{* *} \\
(2.21)\end{array}$ & $\begin{array}{c}0.855^{\star *} \\
(2.27)\end{array}$ & $\begin{array}{l}-0.023 \\
(-0.13)\end{array}$ & $\begin{array}{l}-0.152 \\
(-0.87)\end{array}$ & $\begin{array}{l}-0.093 \\
(-0.34)\end{array}$ & $\begin{array}{l}-3.622 \\
(-1.19)\end{array}$ & $\begin{array}{l}-1.613 \\
(-0.50)\end{array}$ & $\begin{array}{l}-0.329 \\
(-0.10)\end{array}$ \\
\hline NPL ratio, lagged & & $\begin{array}{l}0.099 \\
(1.16)\end{array}$ & $\begin{array}{l}0.089 \\
(0.92)\end{array}$ & $\begin{array}{c}0.128^{\star * *} \\
(4.12)\end{array}$ & $\begin{array}{c}0.142^{\star \star \star} \\
(4.95)\end{array}$ & $\begin{array}{c}0.159^{\star *} \\
(2.24)\end{array}$ & $\begin{array}{l}0.854^{*} \\
(1.98)\end{array}$ & $\begin{array}{l}0.749^{*} \\
(1.75)\end{array}$ & \\
\hline Central bank refin. to total assets, lagged & & & $\begin{array}{l}-0.043 \\
(-0.18)\end{array}$ & $\begin{array}{l}-0.014 \\
(-0.23)\end{array}$ & $\begin{array}{l}-0.007 \\
(-0.09)\end{array}$ & $\begin{array}{l}0.188 \\
(0.74)\end{array}$ & $\begin{array}{l}-1.257 \\
(-0.97)\end{array}$ & $\begin{array}{l}-1.641 \\
(-1.20)\end{array}$ & $\begin{array}{l}-1.359 \\
(-0.99)\end{array}$ \\
\hline Change in NPL ratio, lagged & & & & & & & & & $\begin{array}{c}0.963^{\star *} \\
(2.11)\end{array}$ \\
\hline Country fixed effects & Yes & Yes & Yes & Yes & Yes & Yes & Yes & Yes & Yes \\
\hline Year fixed effects & Yes & Yes & Yes & Yes & Yes & Yes & Yes & Yes & Yes \\
\hline Observations & 1162 & 783 & 745 & 745 & 745 & 745 & 756 & 745 & 702 \\
\hline Number of countries & 105 & 84 & 82 & 82 & 82 & 82 & 83 & 82 & 82 \\
\hline Adjusted R-squared & 0.166 & 0.285 & 0.279 & 0.722 & & & 0.109 & 0.136 & 0.121 \\
\hline Number of instruments & & & & & & 58 & & & \\
\hline $\operatorname{AR}(2)$ test $p$-value & & & & & & 0.836 & & & \\
\hline Hansen test $p$-value & & & & & & 0.585 & & & \\
\hline
\end{tabular}

Note: Constant term included but not reported. $t$-stats based on robust standard errors clustered by country in OLS regressions and robust $z$-stats in system GMM estimation appear in parentheses. ${ }^{* \star *},{ }^{* *},{ }^{*}$ denote significativity at the $1 \%, 5 \%$, and $10 \%$ level, respectively.

Alternative specifications consider the growth rate of banks' claims on the government as the dependent variable (columns (7) to (9)), as in Ongena Popov Van Horen (2016). Results are broadly similar. The level of the NPL ratio or its change explain positively the growth rate of banks' holdings of government debt while the dummy variable for high maturing public debt is never significant. In response to a one-standard deviation increase in the NPL ratio, the growth rate of banks' claims on the government increases by almost 5 percentage points one year later. ${ }^{21}$

Results therefore contrast with those of Ongena Popov Van Horen (2016) or Dell'Ariccia and others (2018) who find a significant effect of maturing public debt on banks' holdings of

\footnotetext{
${ }^{21}$ Alternative regressions include dummy variables for the adoption of Basel II and Basel III standards related to capital and to liquidity (using the database of Jones and Zeitz 2019), which are expected to increase banks' holdings of government debt. These dummy variables are however never significant while results on other variables are qualitatively similar (results not reported).
} 
domestic sovereign securities using bank-level data, a finding interpreted as supportive of financial repression (although in Dell'Ariccia and others (2018), the effect is significant only at the 10 percent level). The discrepancy of the results can reflect several factors. First, these two papers focus on the experiences of banks in Greece, Ireland, Italy, Portugal, and Spain during the acute phase of the European sovereign debt crisis from May 2010 to August 2012, so that their results cannot be generalized to a larger and more diverse sample of countries including normal periods. Second, the effect of maturing debt is found to be only significant for domestic banks (which are more likely than foreign banks to be influenced by the government), especially for those which are state-owned or supported by the government, while in the macroeconomic analysis presented here, observations are mixing all types of banks. ${ }^{22}$ Finally, the crowding-out effect documented by Ongena Popov Van Horen (2016) holds only for credit to households: periods of high government refinancing needs are followed by a reduction of banks' credit to households, but not by a reduction of banks' credit to firms. Overall, while the effect of financial repression/moral suasion on banks' claims on the government and on credit growth may be observed at the microeconomic level for some very specific observations, at the macroeconomic level, this effect clearly does not dominate in the average economy.

The following sub-section examines how banks' holdings of government debt are related to the profitability of the banking sector to further shed light on the importance of the portfolio rebalancing hypothesis.

\section{Banking Sector Profitability}

Claims on the government are expected to increase banking sector profitability thanks to benefits attached to sovereign securities, including:

- Generous interest rates on a risk-adjusted basis. Governments may incite banks to purchase public securities to the detriment of credit to the private sector by offering generous yields on these securities;

- Zero-percent weighting of sovereign securities risk in the computation of bank solvency, implying no extra capital provisions when holding government debt;

- Reduced provisions for loan losses as government securities are in general safer than loans to the private sector;

- $\quad$ Tax deductions. ${ }^{23}$

\footnotetext{
${ }^{22}$ I also considered in the regressions of credit growth to the private sector and of banks' holdings of government debt, the dummy variable for high maturing public debt interacted with a second dummy variable taking the value one if the proportion of domestic banks in the economy is above a given threshold. Results are however qualitatively similar.

${ }^{23}$ Other benefits of government securities include a higher liquidity compared to credit to the private sector; the possibility to use the securities as collateral in central bank's refinancing operations; in some cases, exemptions on exposure and reserve requirements; lower operating costs, as investments in public debt entail lower
} 
Banks' profitability is analyzed using the return on assets (ROA) and the Net Interest Margin (NIM). ${ }^{24}$ A positive relationship between holdings of government debt and banks' ROA could reflect a larger NIM (the net interest income as a share of total assets), a lower capital provision cost, a higher after-tax ROA (implying that the relationship between claims on the government and ROA should be more significant for after-tax than for pre-tax ROA), and a lower loan loss provisioning relative to the NIM (under the portfolio rebalancing hypothesis).

\section{After-Tax ROA}

Banks' after-tax ROA is explained by the following specification:

$$
\begin{aligned}
& \text { ROA }_{i, t}=\gamma_{0}+\gamma_{1} \text { ROA }_{i, t-1}+\gamma_{2} \text { Growth }_{i, t-1}+\gamma_{3} \text { Spread }_{i, t-1}+\gamma_{4}(\text { Assets } / G D P)_{i, t-1}+\gamma_{5} \Delta F X_{i, t-1} \\
& +\gamma_{6} N P L_{i, t-1}+\gamma_{7} \text { GvtExp }_{i, t-1}+\gamma_{8} \text { Banking crisis }_{i, t}+\gamma_{9} \text { Sovereign crisis }_{i, t}+\gamma_{10} \text { Refin }_{i, t-1} \\
& +\gamma_{11} \text { Concentration }_{i, t-1}+\gamma_{12} \text { Oiler }_{i} \times \text { Growth oil prices }_{t-1}+\eta_{i}+\theta_{t}+\varepsilon_{i, t},
\end{aligned}
$$

where Concentration is a measure of the banking sector concentration (the assets of the three largest commercial banks as a share of total commercial banking assets), Oiler $\times$ Growth oil prices is the product of a dummy variable taking the value one if the country is an oil exporter (based on the IMF World Economic Outlook classification) and the annual growth rate of oil prices, and all other variables are the same as those defined before. ${ }^{25}$ In all regressions, the ROA is winsorized at the $5^{\text {th }}$ and $95^{\text {th }}$ percentile to limit the influence of extreme values. ${ }^{26}$

A larger ratio of banks' assets to GDP and a lower market concentration are expected to reduce interest margins and profits, as found by Demirgüç-Kunt and Huizinga (1999). Central bank's refinancing should also be negatively related to profitability, reflecting liquidity difficulties in the sector. Conversely, real GDP growth, the spread between the lending rate and the deposit rate, and the growth rate of oil prices in oil-exporting countries should all raise banks' profitability.

Results of the regressions are reported in Table 3. Explanatory variables are in general significant with the expected sign (with the exception of real GDP growth, only significant in system GMM regressions). The relationship between banks' claims on the government and the ROA is significantly positive in OLS specifications, as well as when using Bruno's

monitoring costs than loans to the private sector. These benefits are however expected to have only an indirect and/or a marginal impact on profitability.

${ }^{24}$ A third common measure of banks' profitability is the Return on Equity (ROE). As noted by Demirgüç-Kunt and Huizinga (1999), this measure can however be misleading, especially in some developing countries where banks are supported by implicit government guarantees and can operate with extremely low equity capital, thus inflating their ROE.

${ }^{25}$ Lagged inflation and real GDP growth volatility have also been included in the regressions, but these variables are never significant, while their inclusion does not alter the results on other regressors.

${ }^{26}$ Several observations show a negative ROA due to banking and/or sovereign crises while some other negative values reflect external shocks like commodity price shocks or conflicts which cannot always be properly captured by the variables in the regressions. 
(2005) correction (columns (1) to (6)), including when banks' claims on the government to total assets are replaced by a dummy equal to one if the variable is above its country-specific median (regression (7)). Results of the Arellano and Bover (1995) and Blundell and Bond (1998) system GMM regressions confirm the positive relationship between banks' holdings of government debt and profitability, although only when the non-linearity of the relationship or the dummy variable for high banks' claims on the government are considered (columns (9) and (10)).

Table 3. Banks' Claims on the Government and After-Tax ROA

\begin{tabular}{|c|c|c|c|c|c|c|c|c|c|c|}
\hline & \multicolumn{10}{|c|}{ Dependent variable: Banks' return on assets } \\
\hline & $\begin{array}{c}\text { OLS } \\
(1) \\
\end{array}$ & $\begin{array}{c}\text { Bruno } \\
(2)\end{array}$ & $\begin{array}{c}\text { Bruno } \\
(3) \\
\end{array}$ & $\begin{array}{c}\text { Bruno } \\
(4) \\
\end{array}$ & $\begin{array}{c}\text { Bruno } \\
(5)\end{array}$ & $\begin{array}{c}\text { Bruno } \\
(6) \\
\end{array}$ & $\begin{array}{c}\text { Bruno } \\
(7) \\
\end{array}$ & $\begin{array}{c}\text { Sys GMM } \\
(8)\end{array}$ & $\begin{array}{c}\text { Sys GMM } \\
(9)\end{array}$ & $\begin{array}{c}\text { Sys GMM } \\
(10)\end{array}$ \\
\hline Banks' return on assets, lagged & $\begin{array}{c}0.249^{\star \star * *} \\
(4.50)\end{array}$ & $\begin{array}{c}0.348^{\star \star \star} \\
(9.23)\end{array}$ & $\begin{array}{c}0.396^{\star \star *} \\
(9.63)\end{array}$ & $\begin{array}{c}0.400^{\star \star \star} \\
(9.24)\end{array}$ & $\begin{array}{c}0.402^{* \star *} \\
(9.29)\end{array}$ & $\begin{array}{c}0.401^{* \star *} \\
(8.79)\end{array}$ & $\begin{array}{c}0.390^{\star \star *} \\
(8.95)\end{array}$ & $\begin{array}{c}0.300^{* * *} \\
(2.71)\end{array}$ & $\begin{array}{l}0.219^{*} \\
(1.91)\end{array}$ & $\begin{array}{c}0.259^{* *} \\
(2.30)\end{array}$ \\
\hline Real GDP growth, lagged & $\begin{array}{l}0.014 \\
(1.44)\end{array}$ & $\begin{array}{l}0.011 \\
(1.26)\end{array}$ & $\begin{array}{l}0.007 \\
(0.91)\end{array}$ & $\begin{array}{l}0.007 \\
(0.66)\end{array}$ & $\begin{array}{l}0.006 \\
(0.57)\end{array}$ & $\begin{array}{l}0.003 \\
(0.40)\end{array}$ & $\begin{array}{l}0.004 \\
(0.39)\end{array}$ & $\begin{array}{c}0.029^{* *} \\
(2.13)\end{array}$ & $\begin{array}{c}0.029^{* * *} \\
(2.81)\end{array}$ & $\begin{array}{c}0.035^{\star \star *} \\
(3.23)\end{array}$ \\
\hline Banks' total assets to GDP, lagged & $\begin{array}{l}-0.003^{*} \\
(-1.82)\end{array}$ & $\begin{array}{l}-0.003 \\
(-1.43)\end{array}$ & $\begin{array}{c}-0.004^{\star *} \\
(-2.01)\end{array}$ & $\begin{array}{l}-0.001 \\
(-0.59)\end{array}$ & $\begin{array}{l}-0.001 \\
(-0.43)\end{array}$ & $\begin{array}{l}-0.001 \\
(-0.41)\end{array}$ & $\begin{array}{l}-0.001 \\
(-0.31)\end{array}$ & $\begin{array}{l}-0.002 \\
(-1.55)\end{array}$ & $\begin{array}{c}-0.003^{\star} \\
(-1.76)\end{array}$ & $\begin{array}{l}-0.003^{*} \\
(-1.87)\end{array}$ \\
\hline Change in average exchange rate, lagged & $\begin{array}{c}0.007^{\star \star \star} \\
(2.79)\end{array}$ & $\begin{array}{c}0.008^{\star *} \\
(2.56)\end{array}$ & $\begin{array}{c}0.008^{* * *} \\
(2.88)\end{array}$ & $\begin{array}{c}0.008^{\star *} \\
(2.43)\end{array}$ & $\begin{array}{c}0.008^{* *} \\
(2.36)\end{array}$ & $\begin{array}{c}0.007^{\star *} \\
(2.12)\end{array}$ & $\begin{array}{c}0.007^{\star *} \\
(2.21)\end{array}$ & $\begin{array}{c}0.012^{\star *} \\
(2.28)\end{array}$ & $\begin{array}{c}0.017^{\star \star \star} \\
(4.09)\end{array}$ & $\begin{array}{c}0.017^{\star \star *} \\
(4.25)\end{array}$ \\
\hline NPL ratio, lagged & $\begin{array}{c}-0.014^{\star *} \\
(-2.15)\end{array}$ & $\begin{array}{c}-0.015^{\star *} \\
(-2.31)\end{array}$ & $\begin{array}{c}-0.018^{\star * *} \\
(-2.73)\end{array}$ & $\begin{array}{c}-0.019^{* * *} \\
(-2.88)\end{array}$ & $\begin{array}{c}-0.020^{* * *} \\
(-2.97)\end{array}$ & $\begin{array}{c}-0.021^{* * *} \\
(-2.66)\end{array}$ & $\begin{array}{c}-0.023^{* * *} \\
(-3.44)\end{array}$ & $\begin{array}{c}-0.024^{* * *} \\
(-3.19)\end{array}$ & $\begin{array}{c}-0.034^{\star * *} \\
(-4.24)\end{array}$ & $\begin{array}{c}-0.029^{* * *} \\
(-3.75)\end{array}$ \\
\hline Banks' claims on gvt. to total assets, lagged & $\begin{array}{c}0.023^{\star * *} \\
(4.25)\end{array}$ & $\begin{array}{c}0.027^{* * *} \\
(3.48)\end{array}$ & $\begin{array}{c}0.022^{* * *} \\
(3.09)\end{array}$ & $\begin{array}{c}0.021^{* * *} \\
(2.62)\end{array}$ & $\begin{array}{c}0.021^{* *} \\
(2.53)\end{array}$ & $\begin{array}{c}0.046^{\star * *} \\
(2.73)\end{array}$ & & $\begin{array}{l}0.004 \\
(0.72)\end{array}$ & $\begin{array}{c}0.030^{* *} \\
(2.03)\end{array}$ & \\
\hline Strict capital reg. $\times$ Banks' claims on gvt., lagged & & & & & & $\begin{array}{l}-0.033^{*} \\
(-1.72)\end{array}$ & & & & \\
\hline Banking crisis dummy & $\begin{array}{c}-0.774^{\star \star *} \\
(-3.60)\end{array}$ & $\begin{array}{c}-0.701^{\star * *} \\
(-3.38)\end{array}$ & $\begin{array}{c}-0.626^{\star * *} \\
(-3.61)\end{array}$ & $\begin{array}{c}-0.628^{\star * *} \\
(-3.87)\end{array}$ & $\begin{array}{c}-0.633^{* * *} \\
(-3.88)\end{array}$ & $\begin{array}{c}-0.569^{* * *} \\
(-3.21)\end{array}$ & $\begin{array}{c}-0.629^{* * *} \\
(-3.94)\end{array}$ & $\begin{array}{c}-0.984^{* * *} \\
(-2.76)\end{array}$ & $\begin{array}{l}-0.818 \\
(-1.33)\end{array}$ & $\begin{array}{c}-0.969^{* *} \\
(-2.52)\end{array}$ \\
\hline Sovereign crisis dummy & $\begin{array}{c}-0.651^{* * *} \\
(-2.86)\end{array}$ & $\begin{array}{c}-0.661^{* *} \\
(-2.55)\end{array}$ & $\begin{array}{c}-0.795^{* * *} \\
(-3.77)\end{array}$ & $\begin{array}{c}-0.787^{* * *} \\
(-3.21)\end{array}$ & $\begin{array}{c}-0.775^{\star * *} \\
(-3.15)\end{array}$ & $\begin{array}{c}-0.800^{* * *} \\
(-3.34)\end{array}$ & $\begin{array}{c}-0.775^{\star \star \star} \\
(-3.21)\end{array}$ & $\begin{array}{c}-0.585^{\star \star} \\
(-2.04)\end{array}$ & $\begin{array}{c}-0.516^{*} \\
(-1.95)\end{array}$ & $\begin{array}{c}-0.439^{*} \\
(-1.87)\end{array}$ \\
\hline Central bank refin. to total assets, lagged & $\begin{array}{l}-0.022 \\
(-1.37)\end{array}$ & $\begin{array}{l}-0.012 \\
(-0.57)\end{array}$ & $\begin{array}{l}-0.008 \\
(-0.47)\end{array}$ & $\begin{array}{l}-0.013 \\
(-0.64)\end{array}$ & $\begin{array}{l}-0.015 \\
(-0.71)\end{array}$ & $\begin{array}{l}-0.016 \\
(-0.79)\end{array}$ & $\begin{array}{l}-0.019 \\
(-0.92)\end{array}$ & $\begin{array}{l}-0.039 \\
(-1.57)\end{array}$ & $\begin{array}{l}-0.034 \\
(-1.55)\end{array}$ & $\begin{array}{l}-0.026 \\
(-1.28)\end{array}$ \\
\hline Banking sector concentration, lagged & & & $\begin{array}{c}0.006^{\star *} \\
(2.33)\end{array}$ & $\begin{array}{c}0.007^{\star \star} \\
(2.54)\end{array}$ & $\begin{array}{c}0.008^{\star * *} \\
(2.62)\end{array}$ & $\begin{array}{c}0.008^{* *} \\
(2.39)\end{array}$ & $\begin{array}{c}0.008^{\star \star *} \\
(2.90)\end{array}$ & $\begin{array}{l}0.005^{*} \\
(1.80)\end{array}$ & $\begin{array}{c}0.006^{\star *} \\
(2.10)\end{array}$ & $\begin{array}{l}0.005^{\star} \\
(1.75)\end{array}$ \\
\hline Spread lending rate-deposit rate, lagged & & & & $\begin{array}{l}0.021^{*} \\
(1.70)\end{array}$ & $\begin{array}{l}0.022^{\star} \\
(1.80)\end{array}$ & $\begin{array}{l}0.022 \\
(1.63)\end{array}$ & $\begin{array}{l}0.019 \\
(1.55)\end{array}$ & $\begin{array}{c}0.016^{\star *} \\
(2.39)\end{array}$ & $\begin{array}{l}0.011 \\
(1.29)\end{array}$ & $\begin{array}{l}0.013^{*} \\
(1.72)\end{array}$ \\
\hline Oil price growth $\mathrm{x}$ oil country dummy, lagged & & & & & $\begin{array}{l}0.005^{*} \\
(1.71)\end{array}$ & $\begin{array}{l}0.006^{*} \\
(1.78)\end{array}$ & $\begin{array}{l}0.005^{\star} \\
(1.73)\end{array}$ & $\begin{array}{l}0.005^{*} \\
(1.82)\end{array}$ & $\begin{array}{l}0.005 \\
(1.61)\end{array}$ & $\begin{array}{l}0.005 \\
(1.56)\end{array}$ \\
\hline 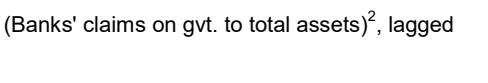 & & & & & & & & & $\begin{array}{c}-0.001^{* *} \\
(-2.03)\end{array}$ & \\
\hline High banks' claims on gvt. / tot. assets, lagged & & & & & & & $\begin{array}{c}0.223^{\star * *} \\
(3.92)\end{array}$ & & & $\begin{array}{c}0.136^{* * *} \\
(2.59)\end{array}$ \\
\hline Country fixed effects & Yes & Yes & Yes & Yes & Yes & Yes & Yes & Yes & Yes & Yes \\
\hline Year fixed effects & Yes & Yes & Yes & Yes & Yes & Yes & Yes & Yes & Yes & Yes \\
\hline No. of observations & 805 & 711 & 671 & 588 & 588 & 584 & 588 & 656 & 573 & 573 \\
\hline No. of countries & 86 & 85 & 75 & 66 & 66 & 65 & 66 & 68 & 66 & 66 \\
\hline No. of instruments & & & & & & & & 29 & 30 & 30 \\
\hline $\operatorname{AR}(2)$ test $p$-value & & & & & & & & 0.106 & 0.305 & 0.170 \\
\hline Hansen test $p$-value & & & & & & & & 0.225 & 0.146 & 0.177 \\
\hline
\end{tabular}

To investigate the importance of reduced capital provision in contributing to the positive relationship between government security holdings and the ROA, I classify countries based on the stringency of their capital regulation, using the index developed by Barth Caprio 
Levine (2013). ${ }^{27}$ In countries where the regulation on capital is more stringent (i.e., countries with an average value of the index above the sample median), the positive relationship between government securities and the ROA is expected to be larger. Extending loans to the private sector in those countries is indeed expected to be costlier in terms of capital provision than in countries with looser capital regulation, so the ROA gains of rebalancing towards public securities should be larger. Results reported in column (6) do not support the capital provision conjecture as the coefficient of the interaction term between the strict capital regulation dummy variable and the banks' claims on the government in total assets is significantly negative. Results (not reported) are qualitatively similar in OLS regressions or when splitting the estimation sample between the two groups of countries, while in GMM specifications, the interaction term is not significant.

\section{Pre-Tax ROA and NIM}

Results of the regressions of the ROA before taxes, reported in Table 4, columns (1) to (6), indicate that the relationship between banks' holdings of government securities and profitability is pretty similar for the ROA before taxes and for the ROA after taxes. A onestandard deviation increase in banks' holdings of government securities $(+8.7$ p.p.) translates the following year into an increase of the ROA after taxes of 0.18 percentage points (for a standard deviation of the dependent variable of 0.93) and into an increase of the ROA before taxes of 0.23 percentage points (for a standard deviation of the dependent variable of 1.18), based on regression (5) of Table 3 and on regression (2) of Table 4, respectively. The finding that the two types of ROAs are equally related to sovereign security holdings suggests that the tax treatment of public securities is not a key factor of the positive relationship between banks' government debt holdings and profitability.

In columns (7) to (10), the dependent variable is the NIM, defined as the ratio of the net interest income to banks' total assets. In contrast to results obtained for the ROA, the NIM is not significantly related to banks' claims on the government, whatever the specification and the estimation technique used, refuting the argument that banks can boost their profitability by purchasing sovereign securities thanks to generous risk-adjusted returns offered by these securities in comparison to loans to the private sector.

Altogether, these results are coherent with the conjecture that lower provisions for loan losses may contribute to the positive relationship between banks' holdings of government debt and the ROA, in line with the portfolio rebalancing hypothesis. From the definition of the ROA before taxes:

ROA before taxes $=N I M+$ Other revenue (includes fee income and profits from trading for own account) - Operating costs - Provisions for loan losses + Realized capital gains from sale of real estate,

${ }^{27}$ Countries with strict capital regulation are found to be relatively diverse in terms of economic development and geographical location. The index on capital stringency is based on replies to the following questions: "Are the sources of funds to be used as capital verified by the regulatory/supervisory authorities?"; "Can the initial disbursement or subsequent injections of capital be done with assets other than cash or government securities?"; "Can initial disbursement of capital be done with borrowed funds?" 
it can be noted that the NIM and the provisions for loan losses are the only components of profitability related to sovereign security holdings and to credit. Given that the ROA is positively associated with government security holdings, but not the NIM, it can be deduced that provisions for loan losses may decrease with banks' holdings of public debt. ${ }^{28}$ Finally, lower operating costs could also explain the positive relationship between sovereign securities and the ROA since government debt is less costly to monitor than private sector loans. Results (not reported) of regressions of the banks' operational cost on holdings of sovereign securities (each variable being expressed as a share of total assets), however, do not indicate any significant relationship between these two variables.

Table 4. Banks' Claims on the Government, ROA Before Taxes, and NIM

\begin{tabular}{|c|c|c|c|c|c|c|c|c|c|c|}
\hline \multirow[t]{2}{*}{ Dependent variable: } & \multicolumn{6}{|c|}{ Banks' return on assets before taxes } & \multicolumn{4}{|c|}{ Net interest margin } \\
\hline & $\begin{array}{c}O L S \\
(1)\end{array}$ & $\begin{array}{c}\text { Bruno } \\
(2)\end{array}$ & $\begin{array}{c}\text { Bruno } \\
(3)\end{array}$ & $\begin{array}{c}\text { Sys GMM } \\
\text { (4) }\end{array}$ & $\begin{array}{c}\text { Sys GMM } \\
\text { (5) }\end{array}$ & $\begin{array}{c}\text { Sys GMM } \\
(6)\end{array}$ & $\begin{array}{c}\text { Bruno } \\
(7)\end{array}$ & $\begin{array}{c}\text { Bruno } \\
(8)\end{array}$ & $\begin{array}{c}\text { Bruno } \\
(9)\end{array}$ & $\begin{array}{c}\text { Sys GMM } \\
(10)\end{array}$ \\
\hline Banks' return on assets before taxes, lagged & $\begin{array}{c}0.330^{* * *} \\
(8.30)\end{array}$ & $\begin{array}{c}0.408^{* * *} \\
(9.28)\end{array}$ & $\begin{array}{c}0.402^{* * *} \\
(9.30)\end{array}$ & $\begin{array}{c}0.307^{\star \star \star} \\
(2.89)\end{array}$ & $\begin{array}{c}0.297^{\star * *} \\
(2.91)\end{array}$ & $\begin{array}{c}0.311^{* * *} \\
(2.91)\end{array}$ & & & & \\
\hline Banks' net interest margin, lagged & & & & & & & $\begin{array}{c}0.461^{\star * *} \\
(12.56)\end{array}$ & $\begin{array}{c}0.469^{* * *} \\
(10.61)\end{array}$ & $\begin{array}{c}0.470^{* * *} \\
(10.65)\end{array}$ & $\begin{array}{c}0.312^{* * *} \\
(2.91)\end{array}$ \\
\hline Real GDP growth, lagged & $\begin{array}{l}0.001 \\
(0.05)\end{array}$ & $\begin{array}{l}0.002 \\
(0.24)\end{array}$ & $\begin{array}{l}-0.000 \\
(-0.04)\end{array}$ & $\begin{array}{l}0.029^{*} \\
(1.87)\end{array}$ & $\begin{array}{l}0.027^{*} \\
(1.69)\end{array}$ & $\begin{array}{l}0.019 \\
(1.12)\end{array}$ & $\begin{array}{c}-0.029^{*} \\
(-1.83)\end{array}$ & $\begin{array}{c}-0.029^{*} \\
(-1.82)\end{array}$ & $\begin{array}{l}-0.028^{\star} \\
(-1.76)\end{array}$ & $\begin{array}{l}0.037 \\
(1.57)\end{array}$ \\
\hline Banks' total assets to GDP, lagged & $\begin{array}{c}-0.004^{* *} \\
(-2.18)\end{array}$ & $\begin{array}{l}-0.003 \\
(-0.98)\end{array}$ & $\begin{array}{l}-0.003 \\
(-0.92)\end{array}$ & $\begin{array}{c}-0.004^{* *} \\
(-2.40)\end{array}$ & $\begin{array}{c}-0.004^{* *} \\
(-2.14)\end{array}$ & $\begin{array}{c}-0.005^{\star *} \\
(-2.37)\end{array}$ & $\begin{array}{c}-0.007^{*} \\
(-1.87)\end{array}$ & $\begin{array}{c}-0.008^{*} \\
(-1.71)\end{array}$ & $\begin{array}{c}-0.008^{*} \\
(-1.66)\end{array}$ & $\begin{array}{c}-0.015^{\star * *} \\
(-3.29)\end{array}$ \\
\hline Change in average exchange rate, lagged & $\begin{array}{c}0.008^{* * *} \\
(3.34)\end{array}$ & $\begin{array}{c}0.009^{* *} \\
(2.36)\end{array}$ & $\begin{array}{c}0.008^{* *} \\
(2.18)\end{array}$ & $\begin{array}{c}0.018^{* * *} \\
(3.77)\end{array}$ & $\begin{array}{c}0.016^{* * *} \\
(3.57)\end{array}$ & $\begin{array}{c}0.015^{\star * *} \\
(2.74)\end{array}$ & $\begin{array}{c}0.026^{* * *} \\
(4.95)\end{array}$ & $\begin{array}{c}0.027^{* * *} \\
(4.10)\end{array}$ & $\begin{array}{c}0.027^{* * *} \\
(4.18)\end{array}$ & $\begin{array}{c}0.045^{\star * *} \\
(5.51)\end{array}$ \\
\hline NPL ratio, lagged & $\begin{array}{c}-0.017^{\star \star} \\
(-2.21)\end{array}$ & $\begin{array}{c}-0.023^{\star * *} \\
(-2.78)\end{array}$ & $\begin{array}{c}-0.026^{* * *} \\
(-3.24)\end{array}$ & $\begin{array}{c}-0.031^{\text {***}} \\
(-3.34)\end{array}$ & $\begin{array}{c}-0.026^{\star * *} \\
(-2.67)\end{array}$ & $\begin{array}{c}-0.026^{\star \star} \\
(-2.47)\end{array}$ & $\begin{array}{c}-0.023^{* *} \\
(-2.26)\end{array}$ & $\begin{array}{c}-0.034^{* * *} \\
(-3.21)\end{array}$ & $\begin{array}{c}-0.033^{* * *} \\
(-3.11)\end{array}$ & $\begin{array}{l}-0.015 \\
(-0.69)\end{array}$ \\
\hline Banks' claims on gvt. to total assets, lagged & $\begin{array}{c}0.022^{* * *} \\
(3.13)\end{array}$ & $\begin{array}{c}0.026^{* * *} \\
(3.05)\end{array}$ & & $\begin{array}{l}0.009 \\
(1.04)\end{array}$ & $\begin{array}{l}0.026^{*} \\
(1.66)\end{array}$ & & $\begin{array}{l}-0.000 \\
(-0.04)\end{array}$ & $\begin{array}{l}-0.008 \\
(-0.67)\end{array}$ & & $\begin{array}{l}-0.002 \\
(-0.16)\end{array}$ \\
\hline Banking crisis dummy & $\begin{array}{c}-0.884^{* * *} \\
(-3.47)\end{array}$ & $\begin{array}{c}-0.818^{* * *} \\
(-3.75)\end{array}$ & $\begin{array}{c}-0.804^{* * *} \\
(-3.73)\end{array}$ & $\begin{array}{c}-1.530^{* * *} \\
(-3.00)\end{array}$ & $\begin{array}{c}-1.616^{\star * *} \\
(-3.22)\end{array}$ & $\begin{array}{c}-1.196^{\star *} \\
(-2.20)\end{array}$ & $\begin{array}{l}-0.336 \\
(-1.04)\end{array}$ & $\begin{array}{l}-0.327 \\
(-0.93)\end{array}$ & $\begin{array}{l}-0.335 \\
(-0.94)\end{array}$ & $\begin{array}{l}-0.812 \\
(-0.81)\end{array}$ \\
\hline Sovereign crisis dummy & $\begin{array}{c}-0.856^{* * *} \\
(-3.59)\end{array}$ & $\begin{array}{c}-1.071^{* * *} \\
(-3.72)\end{array}$ & $\begin{array}{c}-1.074^{\star * *} \\
(-3.79)\end{array}$ & $\begin{array}{c}-0.763^{* *} \\
(-2.42)\end{array}$ & $\begin{array}{l}-0.555 \\
(-1.57)\end{array}$ & $\begin{array}{c}-0.659^{*} \\
(-1.78)\end{array}$ & $\begin{array}{c}-2.205^{* * *} \\
(-5.39)\end{array}$ & $\begin{array}{c}-2.555^{* * *} \\
(-6.35)\end{array}$ & $\begin{array}{c}-2.572^{* * *} \\
(-6.38)\end{array}$ & $\begin{array}{c}-1.535^{\star * *} \\
(-4.38)\end{array}$ \\
\hline Central bank refin. to total assets, lagged & $\begin{array}{l}-0.030^{*} \\
(-1.72)\end{array}$ & $\begin{array}{l}-0.027 \\
(-1.39)\end{array}$ & $\begin{array}{l}-0.031 \\
(-1.58)\end{array}$ & $\begin{array}{l}-0.037 \\
(-1.39)\end{array}$ & $\begin{array}{l}-0.047 \\
(-1.58)\end{array}$ & $\begin{array}{c}-0.059^{*} \\
(-1.66)\end{array}$ & $\begin{array}{l}-0.019 \\
(-0.51)\end{array}$ & $\begin{array}{l}-0.016 \\
(-0.44)\end{array}$ & $\begin{array}{l}-0.016 \\
(-0.42)\end{array}$ & $\begin{array}{l}-0.031 \\
(-0.54)\end{array}$ \\
\hline Banking sector concentration, lagged & $\begin{array}{c}0.007^{* *} \\
(2.33)\end{array}$ & $\begin{array}{l}0.008^{*} \\
(1.87)\end{array}$ & $\begin{array}{c}0.009^{* *} \\
(2.14)\end{array}$ & $\begin{array}{c}0.008^{\star *} \\
(2.34)\end{array}$ & $\begin{array}{c}0.008^{* *} \\
(2.49)\end{array}$ & $\begin{array}{c}0.009^{* *} \\
(2.24)\end{array}$ & $\begin{array}{c}0.017^{* * *} \\
(2.90)\end{array}$ & $\begin{array}{c}0.017^{* * *} \\
(2.84)\end{array}$ & $\begin{array}{c}0.017^{* * *} \\
(2.78)\end{array}$ & $\begin{array}{l}-0.005 \\
(-1.05)\end{array}$ \\
\hline Spread lending rate-deposit rate, lagged & $\begin{array}{l}0.004 \\
(1.64)\end{array}$ & $\begin{array}{l}0.003 \\
(1.01)\end{array}$ & $\begin{array}{l}0.003 \\
(1.05)\end{array}$ & $\begin{array}{l}0.001 \\
(0.29)\end{array}$ & $\begin{array}{l}0.001 \\
(0.44)\end{array}$ & $\begin{array}{l}0.001 \\
(0.16)\end{array}$ & $\begin{array}{l}-0.003 \\
(-0.45)\end{array}$ & $\begin{array}{l}-0.001 \\
(-0.15)\end{array}$ & $\begin{array}{l}-0.001 \\
(-0.16)\end{array}$ & $\begin{array}{l}-0.013 \\
(-1.49)\end{array}$ \\
\hline Oil price growth $\mathrm{x}$ oil country dummy, lagged & & $\begin{array}{l}0.032^{*} \\
(1.92)\end{array}$ & $\begin{array}{l}0.028^{*} \\
(1.74)\end{array}$ & $\begin{array}{l}0.013^{*} \\
(1.81)\end{array}$ & $\begin{array}{l}0.015^{*} \\
(1.95)\end{array}$ & $\begin{array}{l}-0.008 \\
(-0.28)\end{array}$ & & $\begin{array}{c}0.038^{* *} \\
(2.12)\end{array}$ & $\begin{array}{c}0.039^{* *} \\
(2.11)\end{array}$ & $\begin{array}{c}0.064^{* * *} \\
(2.79)\end{array}$ \\
\hline (Banks' claims on gvt. to total assets) ${ }^{2}$, lagged & & & & & $\begin{array}{l}-0.001 \\
(-1.22)\end{array}$ & & & & & \\
\hline High banks' claims on gvt. / tot. assets, lagged & & & $\begin{array}{c}0.252^{* * *} \\
(4.52)\end{array}$ & & & $\begin{array}{c}0.139^{* *} \\
(2.04)\end{array}$ & & & $\begin{array}{l}-0.023 \\
(-0.24)\end{array}$ & \\
\hline Country fixed effects & Yes & Yes & Yes & Yes & Yes & Yes & Yes & Yes & Yes & Yes \\
\hline Year fixed effects & Yes & Yes & Yes & Yes & Yes & Yes & Yes & Yes & Yes & Yes \\
\hline No. of observations & 750 & 586 & 586 & 610 & 646 & 655 & 758 & 660 & 660 & 589 \\
\hline No. of countries & 76 & 66 & 66 & 66 & 67 & 68 & 76 & 68 & 68 & 66 \\
\hline No. of instruments & & & & 29 & 29 & 35 & & & & 28 \\
\hline $\operatorname{AR}(2)$ test $p$-value & & & & 0.125 & 0.124 & 0.115 & & & & 0.975 \\
\hline Hansen test $p$-value & & & & 0.558 & 0.512 & 0.465 & & & & 0.630 \\
\hline
\end{tabular}

${ }^{28}$ Ideally, one should estimate the relationship between government security holdings and the provisions for loan losses, but this is not feasible given the limited availability of this variable. 


\section{Conclusion}

This paper finds that the negative relationship between banks' credit to the private sector and holdings of government securities in EMDEs partly reflects a portfolio rebalancing of banks towards safer and more liquid public assets in stress times. There is, however, no clear evidence that financial repression plays a significant role in explaining this relationship at the macroeconomic level as banks' holdings of government securities are not significantly larger in years when governments face an exogenous increase in their financing needs (i.e., in years of high maturing public debt). Although some papers exploiting bank-level data find evidence that financial repression could be at work in some very specific situations (during crisis times, for state-owned banks or banks receiving government support, and/or for specific borrowers), this finding is not confirmed at the macroeconomic level in more general cases.

Analysis also indicates that banks' profitability increases with holdings of government securities. This relationship, however, does not reflect a favorable tax treatment of sovereign debt (the ROA before and after taxes are equally related to sovereign security holdings) or some generous risk-adjusted yields offered by public securities (contrary to the ROA, the NIM is not related to government security holdings). The negative correlation between banks' claims on the government and credit to the private sector should therefore be interpreted carefully, and not systematically as the sign of a crowding-out effect on credit due to financial repression exerted by governments or some tax incentives and generous riskadjusted yields of public debt in comparison to interest rates on loans to the private sector.

Larger banks' holdings of government securities can nevertheless be a source of concern, despite the fact that portfolio rebalancing appears as an optimal response of banks to a deteriorating quality of private sector loans. First, banks may excessively turn to public debt to the detriment of private sector credit in stress times because of weak credit market institutions. The resilience of credit should in this case be improved by reforming credit reporting systems and the effectiveness of collateral and bankruptcy laws (Djankov McLiesh Shleifer 2007). Second, large holdings of domestic sovereign debt by banks increase risks for loans to the private sector and the economy in case of a sovereign default, on top of triggering a bank-sovereign doom loop. Banks which are the most loaded in domestic sovereigns are indeed those experiencing the sharpest decline in credit to the private sector in the event of a sovereign default, according to empirical evidence by Gennaioli Martin Rossi (2018). Financial stability could therefore be improved by discouraging banks from holding excessive sovereign bonds (e.g., through limits on exposures) while keeping in mind that banks also hold some sovereign bonds as a natural feature of the financial system (Dell'Ariccia and others 2018) and as a result of an optimal business model.

Finally, the finding that banks' profitability increases with claims on the government - which are a priori less risky than loans to the private sector - is puzzling and deserves further investigation. It could for example reflect the short time period of the estimation sample, which includes the global financial crisis, and the weak performance of loans to the private sector in some countries, especially in those where banks have been highly exposed to mortgages and the construction sector. 


\section{REFERENCES}

Altavilla, C., M. Pagano, and S. Saverio. 2016. "Banks Exposures and Sovereign Stress Transmission.” ECB Working Paper No. 1969, October.

Arellano, M. and O. Bover. 1995. "Another Look at the Instrumental Variable Estimation of Error-Components Models.” Journal of Econometrics 68(1), 29-51.

Aschauer, D. 1989. “Does Public Capital Crowd Out Private Capital?” Journal of Monetary Economics 24, 171-188.

Barth, J., G. Caprio, and R. Levine. 2013. "Bank Regulation and Supervision in 180 Countries from 1999 to 2011." National Bureau of Economic Research Working Paper No. 18733.

Becker, B. and V. Ivashina. 2018. "Financial Repression in the European Sovereign Debt Crisis." Review of Finance 22(1), 83-115.

Blundell, R. and S. Bond. 1998. "Initial Conditions and Moment Restrictions in Dynamic Panel Data Models." Journal of Econometrics 87(1), 115-43.

Broner, F., A. Erce, A. Martin, and J. Ventura. 2014. "Sovereign Debt Markets in Turbulent Times: Creditor Discrimination and Crowding-out Effects." Journal of Monetary Economics 61(C), 114-142.

Bruno, G. 2005. "Approximating the Bias of the LSDV Estimator for Dynamic Unbalanced Panel Data Models.” Economics Letters 87(3), 361-366.

Dell'Ariccia G., C. Ferreira, N. Jenkinson, L. Laeven, A. Martin, C. Minoiu, and A. Popov. 2018. "Managing the Sovereign-Bank Nexus.” Departmental Paper No. 18/16, International Monetary Fund, Washington DC.

Demirgüç-Kunt, A. and H. Huizinga. 1999. "Determinants of Commercial Bank Interest Margins and Profitability: Some International Evidence." The World Bank Economic Review 13(2), 379-408.

Djankov, S., C. McLiesh, and A. Shleifer. 2007. "Private Credit in 129 Countries." Journal of Financial Economics 84(2), 299-329, May.

Emran, S. and S. Farazi. 2009. "Lazy Banks? Government Borrowing and Private Credit in Developing Countries.” George Washington University Working Paper No. 9.

Gennaioli, N., A. Martin, and S. Rossi. 2018. "Banks, Government Bonds, and Default: What do the Data Say?" Journal of Monetary Economics 98, 98-113, October.

Guo, K. and V. Stepanyan. 2011. "Determinants of Bank Credit in Emerging Market Economies." Working Paper No. 11/51, International Monetary Fund, Washington DC.

IMF. 2015a. Arab Republic of Egypt, Staff Report for the 2014 Article IV Consultation, Country Report 15/33, January.

- 2015b. "Developments in Central Bank Liquidity Provision: A Harbinger of Wider Macrofinancial Risks in the WAEMU?" Country Report No. 15/101, International Monetary Fund, Washington DC. 
- 2017. Nigeria. Staff Report for the 2017 Article IV Consultation, Country Report 17/80, International Monetary Fund, Washington DC.

—. 2018. "WAEMU Banking System's Soundness and Macro-Financial Linkages." in WAEMU Selected Issues, Country Report No. 18/107, April, International Monetary Fund, Washington DC.

Jones, E. and A. Zeitz. 2019. "Regulatory Convergence in the Financial Periphery: How Interdependence Shapes Regulators' Decisions,” Global Economic Governance Working Paper 141.

Laeven, L. and F. Valencia. 2018. "Systemic Banking Crises Revisited.” Working Paper No. 18/206, International Monetary Fund, Washington DC.

Nickell, S. 1981. "Biases in Dynamic Models with Fixed Effects." Econometrica 49(6), 1417-1426.

Ongena, S., A. Popov, and N. Van Horen. 2016. "The Invisible Hand of the Government: Moral Suasion during the European Sovereign Debt Crisis." DNB Working Papers 505, Netherlands Central Bank, Research Department.

Popov, A. and N. Van Horen. 2015. "Exporting Sovereign Stress: Evidence from Syndicated Bank Lending during the Euro Area Sovereign Debt Crisis." Review of Finance 19(5), 18251866.

Prasad, A., H. Abdel Monem, and P. Garcia Martinez. 2016. "Macroprudential Policy and Financial Stability in the Arab Region." Working Paper No. 16/98, International Monetary Fund, Washington DC.

Roodman, D. 2009. "How to do xtabond2: An Introduction to Difference and System GMM in Stata." Stata Journal, StataCorp LP, 9(1), 86-136, March. 


\section{Appendix Table 1 - Variable Definition and Sources}

\begin{tabular}{|c|c|c|}
\hline Variable & Definition & Sources \\
\hline Credit to the private sector & Commercial banks' claims on the private sector. & IFS and GFSR databases. \\
\hline Banks' total assets & Commercial banks' total assets. & IFS and GFSR databases. \\
\hline Banks' claims on government & Commercial banks' net claims on the domestic government. & IFS and GFSR databases. \\
\hline Domestic deposits & $\begin{array}{l}\text { Difference between total deposits (deposits included in broad } \\
\text { money }+ \text { deposits excluded from broad money) } \\
\text { and foreign currency deposits (liabilities to non-residents). }\end{array}$ & IFS and GFSR databases. \\
\hline Foreign deposits & Commercial banks' liabilities to non-residents. & IFS database. \\
\hline Central bank refinancing & Central bank's claims on other depository corporations. & IFS and GFSR databases. \\
\hline Real GDP growth & Annual growth rate of real GDP. & WEO database. \\
\hline Real GDP growth volatility & GARCH $(1,1)$ measure of GDP growth volatility. & $\begin{array}{l}\text { WEO database and author's } \\
\text { estimations. }\end{array}$ \\
\hline Inflation & Growth rate of the average consumer price index. & WEO database. \\
\hline Deposit rate & Interest rate on deposits. & IFS database. \\
\hline Spread lending rate-deposit rate & Difference between the lending rate and the deposit rate. & $\begin{array}{l}\text { World Bank Global Financial } \\
\text { Development database. }\end{array}$ \\
\hline Exchange rate & Domestic currency units per U.S. dollar, annual average. & WEO database. \\
\hline NPL ratio & Non-performing loans as a share of total loans. & $\begin{array}{l}\text { IMF Financial Soundness } \\
\text { Indicators database. }\end{array}$ \\
\hline Public debt & General government gross debt as a share of GDP. & WEO database. \\
\hline Public investment & Public gross fixed capital formation in percent of GDP. & $\begin{array}{l}\text { WEO database; United Nations } \\
\text { National Accounts. }\end{array}$ \\
\hline Fiscal stress & $\begin{array}{l}\text { Dummy variable taking the value one in years when the public } \\
\text { deficit (i.e., the general government net borrowing as a share } \\
\text { of GDP) increases by more than its country-specific standard } \\
\text { deviation. }\end{array}$ & $\begin{array}{l}\text { WEO database and author's } \\
\text { calculations. }\end{array}$ \\
\hline Banking crisis and sovereign crisis & $\begin{array}{l}\text { Dummy variables for years of systemic banking or sovereign } \\
\text { debt crises. }\end{array}$ & $\begin{array}{l}\text { Laeven and Valencia (2018) } \\
\text { systemic banking crises } \\
\text { database. }\end{array}$ \\
\hline War & $\begin{array}{l}\text { Dummy variable equal to } 1 \text { if the number of deaths in battle } \\
\text { related conflicts is at least } 1,000 \text {. }\end{array}$ & $\begin{array}{l}\text { World Bank, World } \\
\text { Development } \\
\text { Indicators. }\end{array}$ \\
\hline Nominal GDP & Nominal GDP in domestic currency. & WEO database. \\
\hline Banks' net interest margin & $\begin{array}{l}\text { Accounting value of banks' net interest revenue as a share of } \\
\text { their interest-bearing (total earning) assets. }\end{array}$ & $\begin{array}{l}\text { World Bank Financial } \\
\text { Development and Structure } \\
\text { Dataset. }\end{array}$ \\
\hline Banks' ROA before and after taxes & $\begin{array}{l}\text { Commercial banks' pre-tax income and after-tax net income to } \\
\text { yearly averaged total assets. }\end{array}$ & $\begin{array}{l}\text { World Bank Financial } \\
\text { Development and Structure } \\
\text { Dataset. }\end{array}$ \\
\hline Oil Price growth & Annual growth rate of annual average oil price index. & WEO database. \\
\hline Oil country dummy & Dummy variable taking value one for oil exporting countries. & IMF WEO classification. \\
\hline Concentration & $\begin{array}{l}\text { Assets of the three largest commercial banks as a share of total } \\
\text { commercial banking assets. }\end{array}$ & $\begin{array}{l}\text { World Bank Global Financial } \\
\text { Development Database. }\end{array}$ \\
\hline High maturing public debt dummy & $\begin{array}{l}\text { Variable taking the value one if the amount of public maturing } \\
\text { debt as a share of GDP is above its country-specific median, } \\
\text { zero otherwise. Maturing debt is computed as the difference } \\
\text { between the gross financing need and the overall fiscal balance } \\
\text { of the general government. This variable is a proxy of } \\
\text { maturing debt of the government as the gross financing need } \\
\text { concerns the whole public sector and also contains } \\
\text { amortization of debt that is not necessarily maturing during the } \\
\text { year in case repayments are smoothed. }\end{array}$ & $\begin{array}{l}\text { IMF Debt Sustainability } \\
\text { Analysis database, WEO } \\
\text { database, and author's } \\
\text { calculations. }\end{array}$ \\
\hline Capital regulation stringency index & $\begin{array}{l}\text { Index on capital regulation stringency reflecting whether } \\
\text { certain funds may be used to capitalize a bank and whether } \\
\text { their source is verified by the regulatory/supervisory } \\
\text { authorities. }\end{array}$ & Barth Caprio Levine (2013). \\
\hline
\end{tabular}




\section{Appendix Table 2 - Countries of the Estimation Sample}

\begin{tabular}{|l|l|}
\hline \multicolumn{2}{|c|}{ Emerging Market Economies } \\
\hline Bangladesh & Mexico \\
Belarus & North Macedonia \\
Bosnia and Herzegovina & Pakistan \\
Brazil & Philippines \\
Bulgaria & Poland \\
Chile & Romania \\
Colombia & South Africa \\
Croatia & Thailand \\
Hungary & Turkey \\
Indonesia & Ukraine \\
Kosovo & Venezuela \\
Malaysia & \\
\hline \multicolumn{2}{|c|}{ Developing Economies } \\
\hline Albania & Lesotho \\
Algeria & Madagascar \\
Angola & Maldives \\
Armenia & Mauritius \\
Azerbaijan & Moldova \\
Bhutan & Morocco \\
Bolivia & Mozambique \\
Botswana & Namibia \\
Brunei Darussalam & Nicaragua \\
Cambodia & Nigeria \\
Cameroon & Oman \\
Central African Republic & Panama \\
Chad & Papua New Guinea \\
Comoros & Paraguay \\
Congo & Qatar \\
Costa Rica & Rwanda \\
Djibouti & Samoa \\
Dominican Republic & Senegal \\
Ecuador & Serbia \\
Egypt & Seychelles \\
Equatorial Guinea & Sierra Leone \\
Eswatini & Solomon Islands \\
Fiji & Sri Lanka \\
Gabon & St. Vincent and the Grenadines \\
Gambia, The & Tajikistan \\
Georgia & Tonga \\
Ghana & \\
Grenada & Unanda \\
Guatemala & Honduras \\
Kenya & Kuwait \\
Kyrgyz Republic & Note: List of 88 EMDEs composing the estimation sample of \\
regression (1) of Table 1. & \\
\hline
\end{tabular}

